\title{
The youngest Maastrichtian 'true' inoceramids from the Vijlen Member (Gulpen Formation) in northeast Belgium and the Aachen area (Germany)
}

\author{
I. Walaszczyk ${ }^{1, *}$, J.W.M. Jagt ${ }^{2} \&$ N. Keutgen ${ }^{2,3}$
}

1 Uniwersytet Warszawski, Wydział Geologii, Instytut Geologii Podstawowej, Al. Żwirki i Wigury 93, PL-02 089 Warszawa, Poland.

2 Natuurhistorisch Museum Maastricht, de Bosquetplein 6-7, NL-6211 KJ Maastricht, the Netherlands.

3 Present address: UTP Bydgoszczy, ul. Bernardyńska 6/8, PL-85 029 Bydgoszcz, Poland.

* Corresponding author. Email: i.walaszczyk@uw.edu.pl

Manuscript received: October 2009; accepted July 2010

\begin{abstract}
The youngest representatives of 'true' (= non-tegulated) inoceramid bivalves (Inoceramidae) are described from intervals 3-6 of the Vijlen Member (Gulpen Formation), of late early and early late Maastrichtian age, as exposed at quarries and temporary sections in northeast Belgium (CPL SAHaccourt and CBR-Lixhe quarries) and the Aachen area (Germany), i.e. the extended type area of the Maastrichtian Stage. In total, twelve taxa are recognised from levels which are correlative with the Calcaire à Baculites of Manche (France), as well as with the Tercis les Bains section in southwest France, the Wisła (Vistula) River sections (central Poland) and the Western Interior of the United States. Associated cephalopods allow a detailed correlation between biozones based on those groups and on inoceramid bivalves.
\end{abstract}

Keywords: Bivalvia, Inoceramidae, Maastrichtian, Maastrichtian type area, correlation

\section{Introduction}

Recent studies of Late Cretaceous (Campanian-Maastrichtian) inoceramid bivalve faunas have documented their general succession, ranging up to the 'Inoceramus' ianjonaensis Assemblage, the youngest association of what are often referred to as 'true' inoceramids. This assemblage is characterised by a fairly wide geographical distribution, having been recorded to date from Europe, Africa and Madagascar, as well as from the United States Western Interior (Walaszczyk et al., 2009). This implies that the 'Inoceramus' ianjonaensis Assemblage will likely become the prime biocorrelative tool for the midMaastrichtian (Walaszczyk et al., 2008). Until recently, correlation of this inoceramid assemblage with the standard Maastrichtian coleoid (belemnite) succession in northwest Europe was unclear. Although belemnites are associated with 'I.' ianjonanensis morgani in the Calcaire à Baculites, Kennedy (1986, p. 76) noted that only fragments from Fresville and Orglandes were available which, according to Christensen (in Kennedy, 1986), on the basis of Schatzky Distance and alveolar angle, were referable to Belemnitella, and due to their small fissure angle resembled Belemnitella junior. Thus, this provides but a very rough estimate.

Although inoceramids should be quite abundant throughout Europe, also in areas where belemnites are common, we know of no other reasonably large inoceramid and belemnite collections from the lower/upper Maastrichtian interval (in terms of belemnite stratigraphy) outside the Maastricht-Aachen-Liège area. The present faunules originate from the Vijlen Member, the depositional history of which has been unravelled by members of the so-called 'Vijlen Groep' during the past decade. The Vijlen Member occurs in the area between the Roer Valley Graben in the north and the Brabant Massif in the southwest. According to Felder (1997), the thickness of the unit generally varies between 0 and $30 \mathrm{~m}$ between Maastricht, Aachen and Liège, with the exception of two channel structures which are more or less parallel to the Roer Valley Graben, and in which thicknesses of up to $70 \mathrm{~m}$ have been noted. The Vijlen Member is developed in its entirety only within these channels, while at the channel margins and outside these, usually only the higher 
intervals are preserved. At the (extended) type locality, which comprises the Mamelis sunken road (outcrop 62D-79) and the Mamelis borehole (62D-168) sections close to the NetherlandsGermany border, the Vijlen Member is complete, with a subdivision on the basis of bioclasts, foraminifera and ostracods into seven (0-6) intervals (Felder \& Bless, 1994). The foraminifera in the 1-2.4 mm sieve fraction show c. twelve distinct peaks, which have proved useful in the correlation of various sections. Furthermore, peaks in belemnites and bivalves have been used for the same purpose (Felder, 2001). In addition, Felder \& Bless (1994) interpreted changes in the relative frequency of molluscan and echinoderm bioclasts at the Mamelis type section to be indicative of sea level fluctuations and combined these with the appearance of characteristic horizons (i.e., pebble beds, glauconitic layers). The sea level fluctuations can be recognised in the bioclast composition at several outcrops and represent a helpful tool for the correlation of sections.

Based on the established subdivision of the Vijlen Member, its fauna has now been re-evaluated in order to establish a biozonation. However, this approach is hampered by the fact that remanié fossils, especially belemnites, may locally be frequent (Felder, 2001; Keutgen et al., 2010). As a consequence, only the first appearance datum (FAD) of species is considered a reliable bio-event.

Within the Vijlen Member, foraminifera zones C and D of Hofker (1966) have been distinguished, with the latter characterised by the FAD of Bolivinoides draco draco (Marsson, 1878) and restricted to the uppermost $7 \mathrm{~m}$ of this unit at the type locality (Felder \& Bless, 1994). Locally, Zone E may appear within the uppermost Vijlen Member (Robaszynski et al., 1985). Zone $\mathrm{C}$ of the Vijlen Member may be further distinguished, as follows. The lowermost part of this zone is characterised by the FAD of Bolivinoides delicatulus regularis Reiss, 1954 (compare Felder \& Bless, 1994). In the Maastricht-Aachen-Liège area, this taxon has so far only been identified from a few levels within the Vijlen Member, whereas in northern Germany its acme encompasses the uppermost Campanian to lowermost Maastrichtian. Felder \& Bless (1994) also noted that Zone C might be subdivided into a lower portion with Bolivinoides draco miliaris Hiltermann \& Koch, 1950 and Neoflabellina permutata Koch, 1977 and an upper with Nonionella troostae (Visser, 1951). At Mamelis, the boundary between the subzones $C_{\text {lower }}$ and $C_{\text {upper }}$ corresponds roughly to the base of interval 4 of the Vijlen Member and this level is also characterised by a significant change in macrofauna. The first unequivocal records of two index belemnitellids of the upper Maastrichtian, Belemnitella junior Nowak, 1913 and Belemnitella lwowensis Naidin, 1952, are known from slightly above the base of interval 4 (Keutgen et al., 2010).

To date, the most easily applied macrofossil subdivision of the Vijlen Member is based on scaphitid ammonites (Keutgen et al., 2010). However, ammonites have not yet been recorded from intervals $0-2$, because these levels are only rarely exposed. Interval 3 has yielded well-preserved specimens of
Acanthoscaphites (A.) tridens (Kner, 1848); fragments of this species have also been recorded from interval 4. The range of A. (A.) tridens, as currently documented, is uppermost Campanian (Belemnella lanceolata Zone (sensu germanico) to the mid-lower Maastrichtian (Belemnella sumensis Zone (sensu germanico)) (see Niebuhr, 2003; Kin, 2010). However, for material from the Maastricht-Aachen-Liège area, a late early Maastrichtian age (Belemnella cimbrica Zone (sensu germanico)) has been proposed (Jagt et al., 1992). Of note is that the age assignment (early Maastrichtian) of interval 3 is based mainly on the presence of this ammonite species. Within interval 4, Hoploscaphites constrictus (J. Sowerby, 1817) and H. tenuistriatus (Kner, 1848) make their first appearance. While the former is long-ranging (i.e., uppermost Campanian Belemnella lanceolata Zone (sensu germanico) to lowermost Danian; see Machalski, 2005; Machalski et al., 2009), the latter appears confined to the interval between the mid-lower Maastrichtian Belemnella sumensis Zone and the upper Maastrichtian Spyridoceramus tegulatus/Belemnitella junior Zone (sensu germanico) (see Machalski, 2005). Close to the base of interval 6 of the Vijlen Member appears Acanthoscaphites (Euroscaphites) varians blaszkiewiczi Jagt, Kennedy \& Machalski, 1999. At Hemmoor (northern Germany), this subspecies is recorded from equivalents of the upper lower Maastrichtian Belemnella cimbrica Zone to the upper Maastrichtian Tenuipteria argentea/Belemnitella junior Zone (sensu germanico) (see Machalski, 2005). The presence of an interspecies hybrid of Hoploscaphites, which exhibits typical features of the North American Jeletzkytes dorfi Landman \& Waage, 1993 and the European $H$. constrictus, allows correlation of the lower portion of interval 6 with the Hoploscaphites birkelundae Zone of the United States Western Interior (Machalski et al., 2007).

The record of Belemnitella junior and Blt. lwowensis from intervals 4-6 of the Vijlen Member indicates these to correspond with the Spyridoceramus tegulatus/Belemnitella junior Zone (sensu germanico), whereas the top of the member may extend into the lowermost Tenuipteria argentea/Belemnitella junior Zone (sensu germanico) (Keutgen et al., 2010). While belemnites from intervals $0-2$ are not available, those collected from interval 3 seem to favour correlation with the mid- to upper lower Maastrichtian Belemnella sumensis Zone (upper part) or Belemnella cimbrica Zone (sensu germanico). However, the latter interpretation of belemnite data is equivocal (Keutgen et al., 2010).

Keutgen \& Jagt (2009) proposed correlation of the sea level lowstand at the base of interval 4 with Ma3, a major sequence boundary dated at 69.42 Ma by Wornardt (2002) and Vandenberghe et al. (2004) and at 69.23 Ma by 0gg (in litt., June 2009). For comparison, Keutgen \& Jagt (2009) dated the FAD of Belemnitella junior at Hemmoor at 69.2 Ma on the basis of data supplied by Niebuhr (2006), which is well in line with the first unequivocal records of that species from interval 4 in the Maastricht-Aachen-Liège area, slightly above the sequence boundary. Using a sequence-stratigraphic approach, the base 
of the Vijlen Member was correlated with a level which was either close to the base of the Belemnella cimbrica Zone (sensu germanico) (Vandenberghe et al., 2004) or within the Belemnella sumensis Zone (sensu germanico) (Keutgen \& Jagt, 2009).

In summary, the following picture for the Vijlen Member arises from currently available data. Intervals 0-3 are probably of mid- to late early Maastrichtian age, while intervals 4-6 are of early late Maastrichtian age. In comparison with the Kronsmoor-Hemmoor sections in northern Germany, those Vijlen Member intervals that have recently yielded inoceramids (i.e., intervals 3-6) can be dated as follows:

- Interval 3: early Maastrichtian(?), probably upper Belemnella sumensis or Belemnella cimbrica zones;

- Intervals 4-6 (lower portion): Spyridoceramus tegulatus/ Belemnitella junior Zone;

- Interval 6 (upper portion): lowermost Tenuipteria argentea/ Belemnitella junior Zone

Until now, inoceramids from the Vijlen Member in northeast Belgium and the Aachen area have only be treated in a few papers. Dhondt \& Jagt (1987) listed and illustrated a single species, referred to as Inoceramus spec. cf. I. balticus Böhm, from the CPL-SA quarry (Haccourt, Liège, Belgium), which is here reassigned to 'Inoceramus' ianjonaensis. A more complete, albeit still preliminary, study was made on a faunule from the Altembroeck section (Voer, northeast Belgium), where inoceramids were listed and their stratigraphic potential briefly discussed (Dhondt in Jagt et al., 1995). Keutgen (1995, 1996) carried out further work on faunules from the Vijlen Member, inclusive of inoceramid species from the Aachen area. The succession of 'tegulated' inoceramids, Spyridoceramus tegulatus and Tenuipteria argentea, in the Maastrichtian type area, and their stratigraphical importance, has been briefly discussed by Jagt (1999).
The aim of the present paper is to describe inoceramid faunules that have been collected during recent years from strata assigned to the Vijlen Member (Gulpen Formation; sensu Felder, 1975) in northeast Belgium (CPL SA-Haccourt and CBR-Lixhe quarries, province of Liège) and in the Aachen area (Germany) and to integrate them into the existing inoceramid zonation (Fig. 1; Walaszczyk et al., 2009). The inoceramid specimens described herein can also be tied in with wellestablished belemnite zones (Christensen, 1997; Christensen et al., 2004) and the Maastrichtian macrofossil biozonation for northern Germany (Schulz, 1979; Schulz \& Schmid, 1983). As such, they contribute significantly to our understanding of correlations between the chalk facies which is extended over northwest Europe and which is subdivided mainly by means of belemnites, and other rock types elsewhere in Europe (i.e., the Tethyan realm) which do not yield index belemnitellids.

\section{Localities}

Inoceramids studied herein come from intervals 3-6 of the Vijlen Member as exposed at various localities in the area which has also yielded the belemnite faunules described by Keutgen et al. (2010), to which paper reference is made. The ranges of inoceramid species recognised herein are illustrated in Fig. 2.

\section{Schneeberg near Lemiers (Vaals)}

At the Schneeberg near Lemiers, close to the NetherlandsGermany border (see Keutgen et al., 2010, fig. 8), several small outcrops were accessible during the nineteenth century, where the so-called 'Bakovensteen van Lemiers', a pure, white, finegrained marly limestone, was quarried. Specimens in museum collections, such as Trochoceramus cf. radiosus (Quaas, 1902) may stem from this locality. At present, fossils can still be

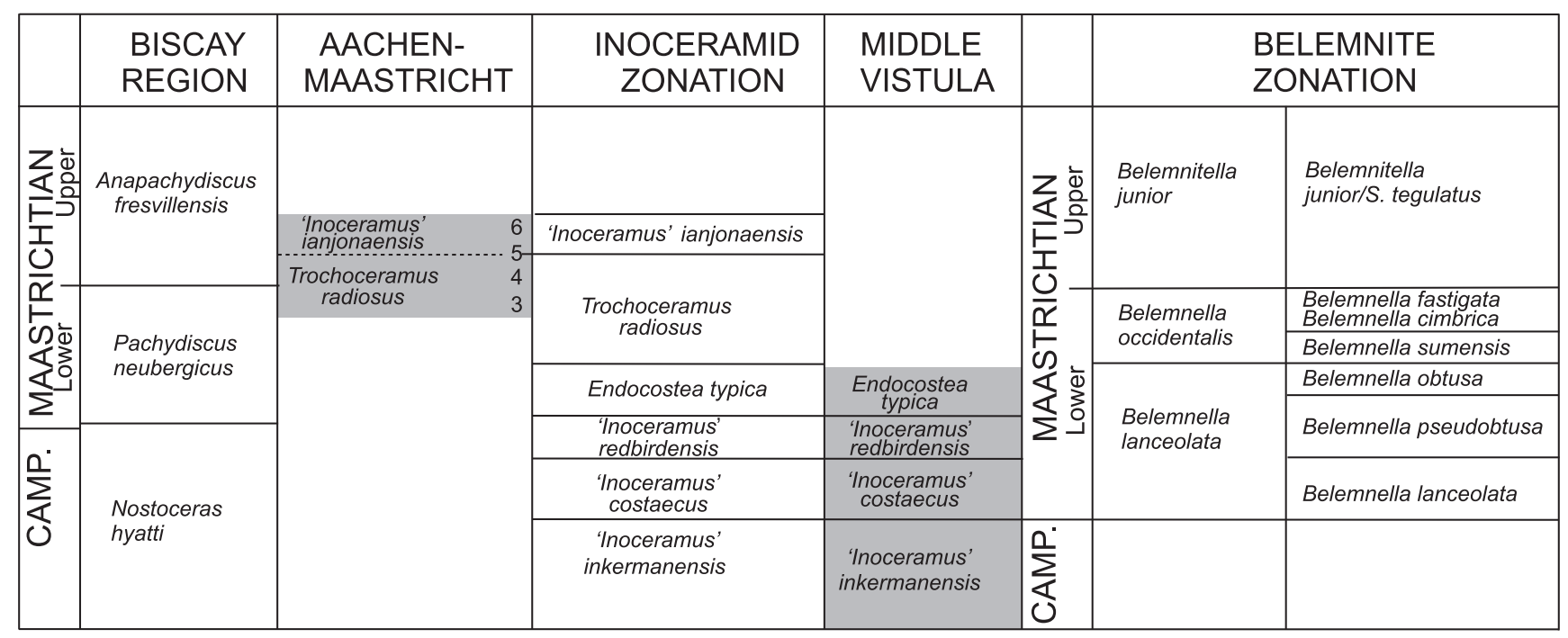

Fig. 1. Correlation of inoceramid/ammonite/belemnite schemes for the uppermost Campanian, lower and lowermost upper Maastrichtian. Correlation with the Bay of Biscaye area is based on Ward \& Kennedy (1993); with the Wista sections (central Poland) on Walaszczyk (2004) and Remin (2007). 


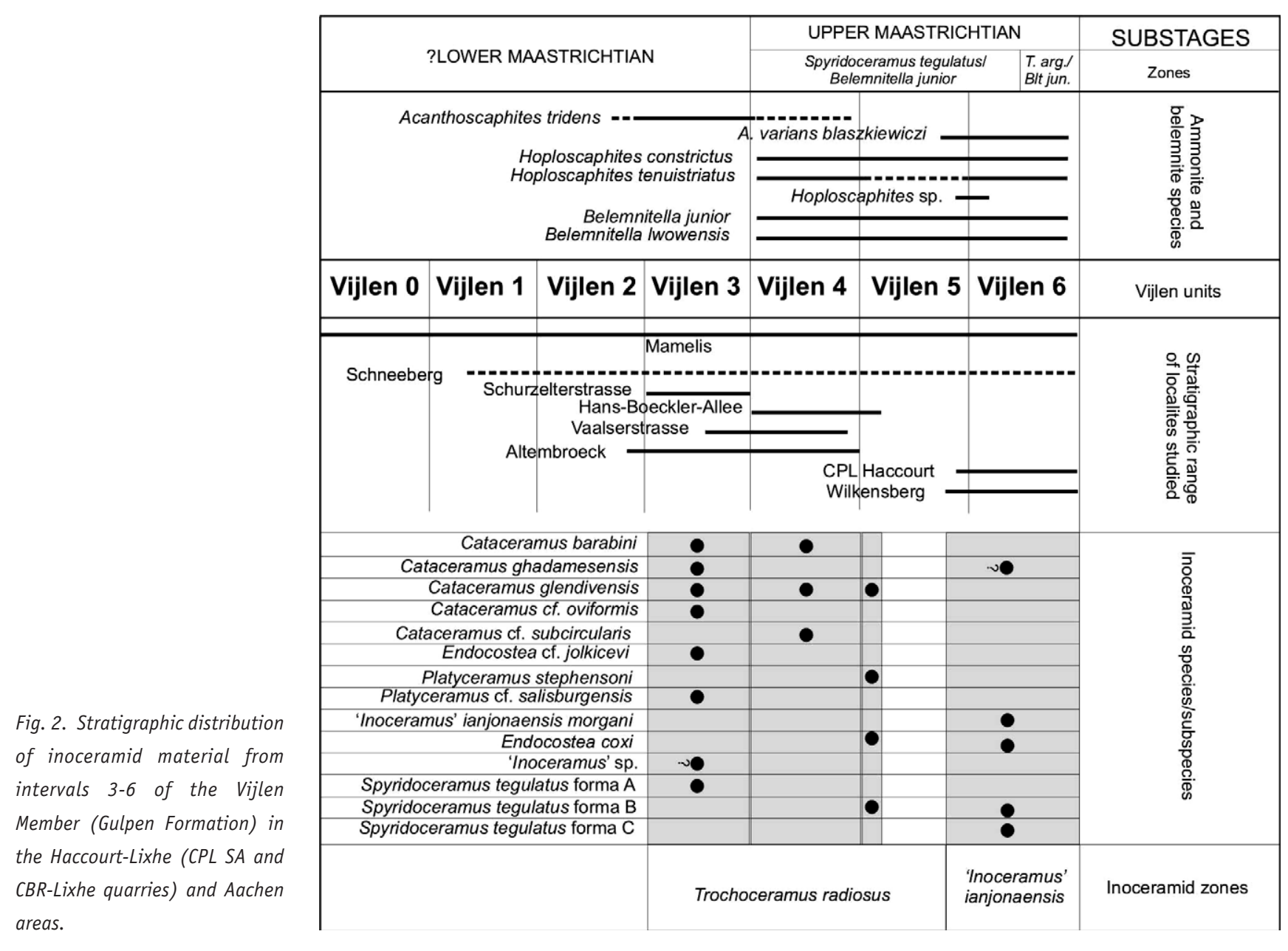

collected from nearby fields. From material contained in the collections of the Rheinische Friedrich-Wilhelms-Universität Bonn or formerly on exhibit in the students' collections of the Institute of Palaeontology (Rheinisch-Westfälische Technische Hochschule, Aachen), studied by one of us (NK), we assume that these outcrops exposed at least intervals 3 and 4 and, most probably, older intervals ( 1 and 2 ) as well. Worthy of note is that at the Schneeberg also intervals 5 and 6 have been documented, and these are overlain by the late Maastrichtian Orsbach Member, a local facies equivalent of the Lixhe Member (Van der Ham \& Van Birgelen, 1992).

\section{Schurzelterstraße and Hans-Böckler-Allee}

The temporary section Schurzelterstraße (Aachen) was first described by Keutgen \& van der Tuuk (1991). It comprised several short-term exposures, accessible between 1978 and 1981 during construction of houses at numbers 460-565. Towards its top, the Schurzelterstraße section is complemented by the Hans-Böckler-Allee section ( $8.4 \mathrm{~m})$, which comprised the construction sites of houses at numbers 40-42. While the deposits of Schurzelterstraße exposed a yellow-grey, marly limestone, those at Hans-Böckler-Allee revealed an alternation of glauconite-rich beds and marlstones or marly limestones with low glauconite content. Felder \& Bless (1994) analysed a bioclast sample from Hans-Böckler-Allee and correlated it with their interval 4. Hence, the underlying deposits formerly exposed at Schurzelterstraße are correlated with interval 3. The locality Schurzelterstraße yielded well-preserved specimens of $A$. (A.) tridens, while the locality Hans-Böckler-Allee yielded the first specimens of $H$. constrictus.

\section{Vaalserstraße}

This temporary section at Aachen exposed the transition between intervals 3 and 4 (see Keutgen et al., 2010, fig. 8). Spyridoceramus tegulatus (Von Hagenow, 1842) was collected from the lower portion of the section exposed, from which also a well-preserved specimen of $A$. (A.) tridens has been recorded (Jagt et al., 1999). It may thus have come from interval 3.

\section{Wilkensberg}

Near the RWTH Aachen computer museum (Melatener Straße), the top of the Vijlen Member (uppermost metres of interval 5, plus interval 6) were exposed temporarily. These strata are correlated with the upper Spyridoceramus tegulatus/Belemnitella junior Zone and the lowermost Tenuipteria argentea/Belemnitella 
junior Zone (sensu germanico) (Keutgen et al., 2010). At this locality, the index scaphitid A. varians blaszkiewiczi was collected.

\section{Haccourt-Lixhe area}

The former Ciments Portland Liégeois (CPL) quarry, Haccourt, and the nearby CBR-Lixhe quarry, are situated on the left bank of the River Maas, about $10 \mathrm{~km}$ south of Maastricht, in the Belgian province of Liège (see Keutgen et al., 2010, fig. 8). These quarries expose the uppermost portion of interval 5, plus interval 6, and biota collected here are coeval with those from the Wilkensberg near Aachen, as indicated by records of $A$. varians blaszkiewiczi.

\section{Discussion}

\section{Inoceramid succession}

The inoceramid species recognised to date (Figs 3-9) represent two stratigraphical assemblages, referred to herein as the Cataceramus Assemblage (which characterises intervals 3, 4 and the lower portion of interval 5) and the 'Inoceramus' ianjonaensis Assemblage, typical of the upper portion of interval 5, in addition to interval 6. These assemblages are dominated by their index taxa; additionally, nearly the entire Vijlen Member succession, with the exception of interval 4, is characterised by the occurrence of a tegulated species, Spyridoceramus tegulatus.

The Cataceramus Assemblage is dominated by Cataceramus glendivensis; other associated taxa are rare and/or taxonomically equivocal. Amongst other taxa are: Cataceramus barabini, C. ghadamesensis, C. cf. oviformis, Platyceramus cf. salisburgensis, 'Inoceramus' sp. and Endocostea cf. jolkicevi. A single specimen of Trochoceramus cf. radiosus (Fig. 5), from a locality near Vaals (?Schneeberg) which probably exposed the lower portion (i.e., below interval 3) of the Vijlen Member, is contained in the collections of the Rheinische Friedrich-Wilhelms-Universität Bonn.

The younger lot, referred to herein as the 'I.' ianjonaensis Assemblage, is well represented in both the Haccourt-Lixhe and Aachen areas. It is represented by 'Inoceramus' ianjonaensis morgani, a geographical subspecies, and by Endocostea coxi. Although the latter species is poorly represented in our material (three specimens only), it is the form that is coeval with ' $I$. ' ianjonaensis in other stratigraphically equivalent faunas, having been recorded from Zululand (Walaszczyk et al., 2009), France (Calcaire à Baculites) and Nigeria (Reyment, 1955; López et al., 2004).

A more detailed analysis of the inoceramid succession reveals that species richness in Vijlen Member interval 3 is comparatively high. The six specimens of 'true' inoceramids collected from this interval are assigned to six different species. For interval 3, the presence of Cataceramus ghadamesensis, which was first described from a level just below the first occurrence of 'Inoceramus' ianjonaensis Sornay, 1973 (see Tröger \& Röhlich, 1981), supports the proposed dating as Belemnella cimbrica Zone of these deposits. Spyridoceramus tegulatus is represented by forma A, which is characterised by an axially elongated, slender form with concentric rugae that dominate the pattern of ornament, and radial elements that form lines of nodes at the intersection with the concentric rugae.

Interval 4 as exposed at Hans-Böckler-Allee yielded six specimens of 'true' inoceramids, representing merely three species. With four specimens, Cataceramus glendivensis dominates this impoverished assemblage. Spyridoceramus tegulatus is notably absent from this assemblage, indicating that this species might have temporarily become absent in the study area, near the lower/upper Maastrichtian boundary as defined by the FAD of Belemnitella junior at the base of interval 4 (see Keutgen et al., 2010).

Based on inoceramid faunas, interval 5 should be subdivided into a lower and an upper portion. The lower portion, as exposed at Hans-Böckler-Allee, has yielded an assemblage that differs from that of the upper levels as exposed at Wilkensberg and in the Haccourt-Lixhe area. The fauna of the lower portion of interval 5 clearly is transitional between the Cataceramus Assemblage and the 'Inoceramus' ianjonaensis Assemblage. While the last representatives of the former, such as $C$. glendivensis and Platyceramus stephensoni, are still present in significant numbers, a typical element of the latter assemblage, $E$. coxi, appears for the first time. However, the index, 'I.' ianjonaensis, is missing. Of note is the fact that representatives of $S$. tegulatus re-appear at this level, but they belong to forma B, a less slender morphotype with an ornament composed almost exclusively of concentric rugae.

Typical representatives of 'I.' ianjonaensis and E. coxi are found in the uppermost portion of interval 5 and in interval 6 . Twelve 'true' inoceramid specimens have been collected, nine of them assignable to the index taxon, while only a single member of the Cataceramus Assemblage, C. ghadamesensis, has been recorded from these levels, which correspond roughly to the upper Spyridoceramus tegulatus/Belemnitella junior Zone of northern Germany (Schulz \& Schmid, 1983). In the MaastrichtAachen-Liège area, this youngest fauna of 'true' inoceramids is further impoverished. Spyridoceramus tegulatus forma B is still present, but in the Haccourt-Lixhe area rare representatives of forma $\mathrm{C}$, with very strong radial ornament, co-occur with it. of note is a similar drop in species-level variability in this youngest inoceramid assemblage in Zululand (Walaszczyk et al., 2009).

\section{Inoceramid stratigraphy and correlations}

Three successive inoceramid zones, defined as interval range zones of the index taxa (see Fig. 1), have recently been 
recognised in the Maastrichtian of the Euramerican biogeographic region and Africa (Walaszczyk et al., 1996, 2001, 2002a, b; Walaszczyk, 2004; Walaszczyk et al., 2009). These are, in ascending order, the Endocostea typica, Trochoceramus radiosus and 'Inoceramus' ianjonaensis zones.

The base of the Endocostea typica Zone is situated slightly above the Campanian/Maastrichtian boundary as currently defined, i.e. above the average level of twelve bio-events as recognised in the stratotype at Tercis les Bains, Landes (France; see Odin, 2001; Odin \& Lamaurelle, 2001; Walaszczyk et al., 2002b). Consequently, the Campanian/Maastrichtian boundary, in inoceramid terms, should be placed somewhere within the underlying 'Inoceramus' redbirdensis Zone, as discussed by Walaszczyk et al. (2002a, b) and 0din \& Walaszczyk (2003). As demonstrated at Tercis les Bains and, in part, in the Wisła (Vistula) River sections (central Poland), both the E. typica and T. radiosus zones correspond to the Pachydiscus neubergicus Zone, defined as an interval from the FAD of the index taxon to the FAD of Menuites fresvillensis (Seunes, 1890) (see Walaszczyk et al. 2002b, 2009). The base of the successive zone of 'Inoceramus' ianjonaensis and its European equivalent, the 'Inoceramus' ianjonaensis morgani Zone, as documented in successions in Spain and Zululand (Ward et al., 1991; Ward \& Kennedy, 1993; MacLeod, 1994), approximates the lower boundary of the Menuites fresvillensis Zone.

The correlation between ammonites and inoceramids thus seems well established. However, correlation of the inoceramid zonation and the northwest European belemnite scheme is still poorly constrained. In the chalk succession of HemmoorKronsmoor (northern Germany), where the lower Maastrichtian belemnite standard was established (Schulz, 1979; Schulz \& Schmid, 1983; Schulz et al., 1984; Schönfeld et al., 1996), true inoceramids are only known from unidentifiable fragments (Dhondt, 1982). In contrast, both groups are well represented in the Wisła River section, central Poland (Walaszczyk, 2004). A renewed study of late Campanian and early Maastrichtian belemnites, documented almost 50 years ago by Kongiel (1962), has recently been carried out by Remin (2007). According to these data, the base of the E. typica Zone falls within the Belemnella pseudobtusa Zone, and the zone itself spans the upper part of that zone and ranges into the succeeding Belemnella obtusa Zone. Unfortunately, the higher part of the succession, corresponding to the Trochoceramus radiosus to 'Inoceramus' ianjonaensis zones, is not exposed along the Wisła River. The present inoceramid material from the Maastricht type area is thus of prime importance for belemnite-inoceramid intercorrelation. The data presented here correlate the base of the 'Inoceramus' ianjonaensis Zone to a level within the Spyridoceramus tegulatus/Belemnitella junior Zone (see Schulz \& Schmid, 1983; Jagt, 1999) (Fig. 1). According to data from the Wisła River section, the Endocostea typica Zone spans the upper Belemnella pseudobtusa and Belemnella obtusa zones, implying that the Trochoceramus radiosus Zone is equivalent to the Belemnella sumensis, Belemnella cimbrica and Belemnella fastigata zones, which in turn would correspond to the traditional Belemnella occidentalis Zone and lower Spyridoceramus tegulatus/Belemnitella junior Zone. Keutgen \& Jagt (2009), on the basis of a correlation between northern Germany (combined Kronsmoor-Hemmoor sections) and the United States Western Interior, plus the documented range of Trochoceramus radiosus in the latter area, proposed that this taxon could be expected to occur in most of the Belemnella sumensis Zone as well as in the lower Belemnella cimbrica Zone. This implies an informal subdivision of the Trochoceramus radiosus Zone into a lower assemblage with the index and related taxa (Trochoceramus Assemblage) and an upper one without these (Cataceramus Assemblage).

\section{Inoceramid zonation in the Maastricht-Aachen- Liège area}

Based on the stratigraphic ranges of inoceramid assemblages recognised in the area, two successive inoceramid zones are distinguished in the interval studied; the Trochoceramus radiosus Zone (spanning intervals 3, 4 and the lower portion of 5) and the 'Inoceramus' ianjonaensis Zone, encompassing the upper portion of interval 5, plus interval 6 (Figs 1,2). The distinction of the latter zone is straightforward, and it comprises the stratigraphic interval of the 'I.' ianjonaensis Assemblage. It is defined by the FAD of the index species, here represented by its geographic subspecies, 'I.' ianjonaensis morgani. The upper boundary of the zone is defined by the last occurrence of ' $T$.' ianjonaensis. The $T$. radiosus Zone comprises the stratigraphic interval of the Cataceramus Assemblage. The distinction of $T$. radiosus Zone is based on its stratigraphic position below the 'I.' ianjonaensis Zone and on a single questionable (cf.) specimen of the index species. Based on the inoceramid fauna alone it is impossible to state which part of the zone is actually represented in the succession studied.

\section{Systematic palaeontology}

Our material is quite rich, consisting of a total of sixty-three specimens. Preservation, however, is variable. Most specimens are internal moulds of a single, usually incomplete, valve. Only a few specimens are articulated; some specimens are external moulds. In addition, most are usually deformed, commonly having suffered lateral or oblique compression.

Morphological terms and measurements applied herein follow Harries et al. (1996), and are as follows: $\Delta$ - anterior hinge angle; $\delta$ - angle between growth axis and hinge line (obliquity); $\mathrm{h}$ - axial length; $\mathrm{l}$ - length perpendicular to $\mathrm{h} ; \mathrm{H}$ - valve height; $\mathrm{L}$ - valve length; $\mathrm{HL}$ - hinge line; B - convexity.

With one exception, all material is housed in the collections of the Natuurhistorisch Museum Maastricht (abbreviation: NHMM; JJ - J.W.M. Jagt Collection; NK - N. Keutgen Collection). 
Three specimens are contained in collections at the Museen der Stadt Aachen (abbreviation: MSA). Other abbreviations are as follows: UB - Rheinische-Friedrich-Wilhelms University, Bonn; NHM - The Natural History Museum, Department of Palaeontology, London; USNM - United States National Museum, Washington DC; YPM - Peabody Museum, Yale University, New Haven.

Family Inoceramidae Giebel, 1852

Genus Cataceramus Heinz, 1932

\section{Type species}

Inoceramus balticus Böhm, 1907.

Cataceramus barabini (Morton, 1834) sensu Meek, 1876

Figs $3 / 5,4 / 5$.

Compare:

1876 Inoceramus Cripsii?, var. Barabini Morton; Meek, p. 49, pl. 12, fig. 3; text-figs 1-4 (?pl. 13, fig. 1).

1995 Inoceramus (Endocostea) balticus subsp. Böhm; Keutgen, p. 298, pl. 7, fig. 1.

\section{Material}

Two specimens: NHMM NK 23 (Schurzelterstraße, interval 3) and NHMM NK 5 (Hans-Böckler-Allee, interval 4).

\section{Description and remarks}

Both specimens are internal moulds of single left valves. NHMM NK 23 is a large $\left(h_{\max }=107 \mathrm{~mm}\right)$, adult specimen, secondarily compressed perpendicular to the commissural plane, which results in a higher valve inflation. NHMM NK 5 is a juvenile fragment (hmax $=48.6 \mathrm{~mm})$, with posterior and postero-ventral parts missing. Both specimens are of a 'balticus'-like morphotype, with high obliquity $\left(\delta=30^{\circ}\right)$, a distinct posterior elongation, a long and straight hinge line and a short and convex anterior margin. The ornament is composed of regularly/subregularly spaced commarginal rugae.

Both specimens closely resemble Inoceramus Cripsii?, var. Barabini Morton as interpreted by Meek (1876, p. 49, pl. 12, fig. 3; text-figs 1-4), from the lower Maastrichtian of the United States Western Interior. The relationship of Meek's form to Morton's is unclear.

\section{Occurrence}

The present specimens are from intervals 3 and 4. Meek's type is from the lower Maastrichtian of the United States Western Interior.
Cataceramus ghadamesensis (Tröger, in Tröger \& Röhlich, 1981)

Figs $3 / 2,3$.

1981 Inoceramus (Selenoceramus) ghadamesensis Tröger, in Tröger \& Röhlich, p. 170, pls 1, 2; text-fig. 2.

1991 Inoceramus (Selenoceramus) ghadamesensis Tröger et Röhlich; Tröger \& Röhlich, p. 1368, pl. 3, figs 1-5, 8-10.

non2000 Endocostea cf. ghadamesensis (Tröger \& Röhlich, 1981); Dhondt in Robaszynski et al., p. 414, pl. 11, fig. 3; text-fig. 43.

\section{Type}

Holotype, by original designation, is specimen no. 1285-II-B4/22, the original of Tröger, in Tröger \& Röhlich (1981, pl. 2, fig. 1), from the Lower Tàr Member (Zimam Formation; lower Maastrichtian) near Ghadames, Libya.

\section{Material}

Two specimens: NHMM JJ 8636 (CBR-Lixhe quarry, interval 6) and NHMM NK 36 (Schurzelterstraße, interval 3).

\section{Description}

Small- to moderate-sized $\left(\mathrm{h}_{\max }=55 \mathrm{~mm}\right.$ in NHMM JJ 8636 and $65 \mathrm{~mm}$ in NHMM NK 36), equivalve, strongly inequilateral species. Valves show two growth stages, separated by a more or less distinctly developed geniculation; the juvenile stage is small (approximately $20 \mathrm{~mm}$ in h length in both specimens), subrounded in outline, and ornamented with regularly and finely spaced commarginal rugae. The adult stage is elongated strongly postero-ventrally (adult $\delta$ values reach about $20^{\circ}$ ), weakly ornamented with irregular, low rugae or is almost smooth. The hinge line is long and straight; the umbo small, not projecting above hinge line. A 'hohlkehle' usually is present, starting in the median part of the juvenile stage and continuing onto the adult.

\section{Remarks}

Juveniles are indistinguishable from those of small-sized ' $I$.' ianjonaensis morgani, but these species differ in the adult stage; C. ghadamesensis has a strongly posteriorly extended shell in the adult stage, and the juvenile stage is weakly separated; moreover, its adult ornament is composed almost entirely of growth lines, with rare irregular rugae in the ventralmost parts. None of the specimens illustrated and referred to $C$. ghadamesensis by Dhondt (in Robaszynski et al., 2000) can be confirmed as conspecific; one of her specimens (text-fig. 43) is a transitional form between 'Inoceramus' gandjaeformis and 'Inoceramus' alaeformis, well represented in the uppermost Campanian (see Walaszczyk, 2004, fig. 44A, C, D, F); the one in pl. 11, fig. 3 is difficult to determine, but may be close to 'Inoceramus' oblongus. 

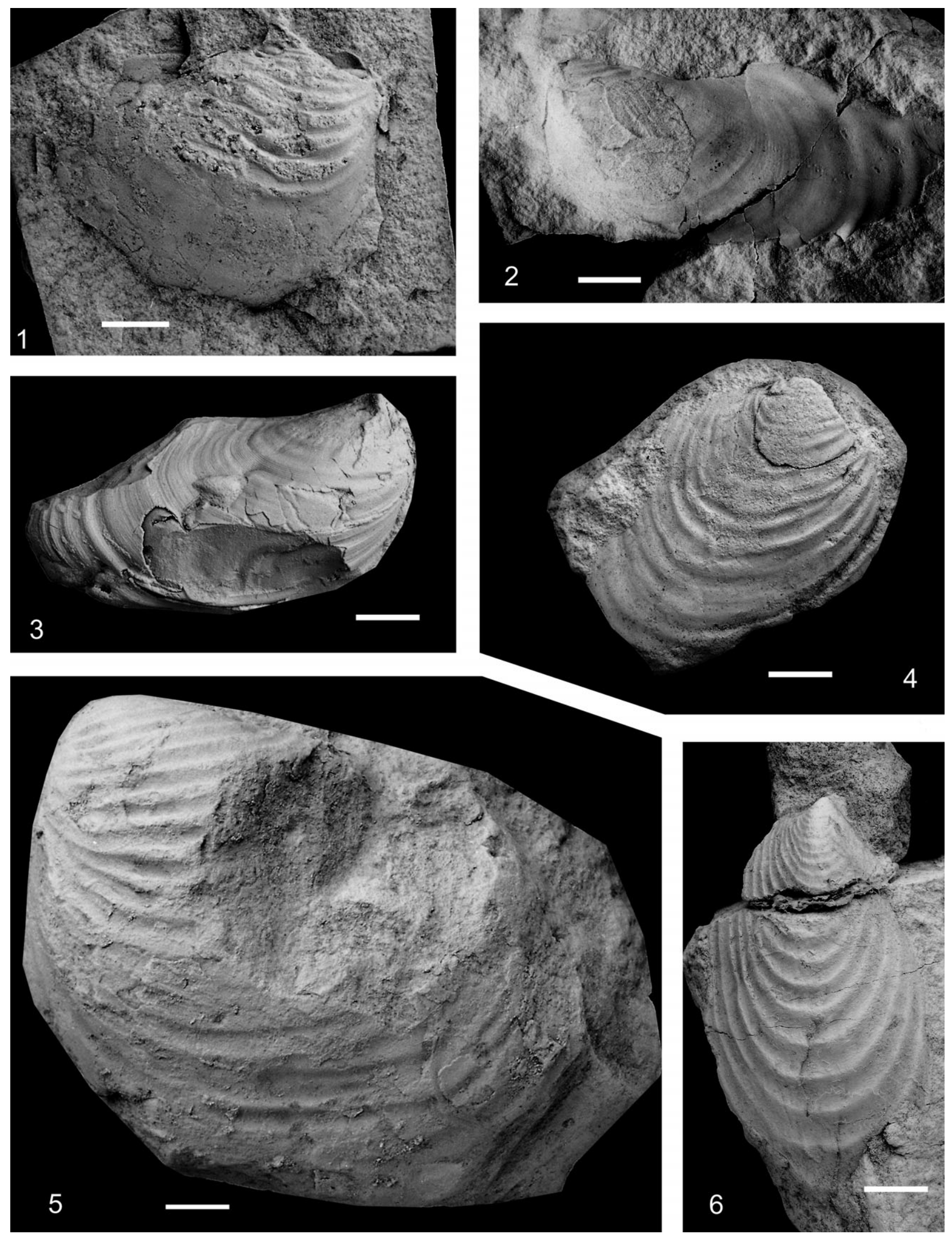

Fig. 3. Inoceramids of the Vijlen Member; 1. Endocostea cf. jolkicevi Walaszczyk, Odin \& Dhondt, 2002 (NHMM NK 17; Schurzelterstraße, interval 3); 2, 3. Cataceramus ghadamesensis (Tröger, in Tröger \& Röhlich, 1981) (NHMM NK 36; Schurzelterstraße, interval 3, and NHMM JJ 8636; CBR-Lixhe quarry, interval 6); 4. Cataceramus glendivensis Walaszczyk, Cobban \& Harries, 2001 (NHMM NK 3; Hans-Böckler-Allee, interval 4); 5. Cataceramus barabini (Morton, 1834) sensu Meek, 1876 (NHMM NK 23; Schurzelterstraße, interval 3); 6. Cataceramus cf. subcircularis (Meek, 1876) (NHMM NK 18 II; HansBöckler-Allee, interval 4). All scale bars represent $10 \mathrm{~mm}$. 


\section{Occurrence}

In the Maastricht-Aachen-Liège area, this species is known from intervals 3 and 6, which, in belemnite terms, equate with the upper Belemnella cimbrica and Belemnitella junior zones (Fig. 2). Cataceramus ghadamesensis was first described from the lower Maastrichtian of northwest Libya, from a level just below the first occurrence of 'Inoceramus' ianjonaensis Sornay, 1973 (see Tröger \& Röhlich, 1981). The late Campanian-early Maastrichtian forms (Abiod and basal El Haria formations) referred to this species from western Tunisia (Dhondt in Robaszynski et al., 2000) represent different species.

Cataceramus glendivensis Walaszczyk, Cobban \&

Harries, 2001

Figs $3 / 4,4 / 2,3,7$.

2001 Cataceramus? glendivensis Walaszczyk et al., p. 170, pl. 42, figs 2, 11; pl. 44, figs 2, 4 .

\section{Type}

Holotype, by original designation, is YPM 191001, the original of Walaszczyk et al. (2001, pl. 42, fig. 2) from the upper part of the Baculites baculus Zone (lower lower Maastrichtian) of the Glendive section, Montana (USA).

\section{Material}

Six specimens: NHMM NK1 (Schurzelterstraße, interval 3); NHMM NK 2 (+ corresponding outer mould, NHMM NK 29), NHMM NK 3, ?NHMM NK 8 and NHMM NK 38 (all Hans-BöcklerAllee, interval 4); NHMM NK 24 (+ corresponding counterpart, NHMM NK 26) (Hans-Böckler-Allee, interval 5).

\section{Dimensions}

(linear; in $\mathrm{mm}$ ):

\begin{tabular}{llllllllll}
\hline & valve & $\mathbf{h}_{\max }$ & $\mathbf{h}$ & $\mathbf{l}$ & $\mathbf{H}$ & $\mathbf{L}$ & $\mathbf{H L}$ & $\boldsymbol{\Delta}$ & $\mathbf{\delta}$ \\
\hline NHMK NK 24 & LV & 49 & 48 & 42 & 39.5 & 40 & $21.5^{*}$ & 108 & 55 \\
NHMK NK 38 & LV & 65 & 55 & 47 & 47 & 50 & 27 & 110 & 55 \\
NHMK NK 2 & RV & 71 & - & - & - & - & - & - & - \\
NHMK NK 3 & RV & $46^{*}$ & - & - & - & - & - & - & $45^{*}$ \\
\hline
\end{tabular}

\section{Description}

These specimens represent medium-sized forms, weakly inflated, inequilateral, presumably equivalve or nearly so. The species is moderately oblique, with the $\delta$ angle between 45 and $55^{\circ}$. The anterior margin is moderately long, straight or slightly convex, and passes into a long, broadly convex antero-ventral margin. The ventral margin is rounded, the hinge line moderately long and straight.

Ornament consists of subregular, low and delicate, concentric rugae; growth lines are rarely observed; these are better preserved in NHMM NK $24(+26)$, in which they are oblique to the rugae.

\section{Remarks}

Cataceramus glendivensis is similar to 'Inoceramus' bebahoensis, described by Sornay (1973) from the Maastrichtian of Madagascar. Although one of the specimens illustrated by Sornay (1973, pl. 3, fig. 2) closely resembles the North American C. glendivensis, the Madagascan material is represented by rather massive, moderately inflated specimens.

\section{Occurrence}

This North American species was described from the lower Maastrichtian (Baculites baculus Zone) and from the successive Baculites grandis Zone. It has subsequently been recorded from the lower Maastrichtian of Piesting (Austria; Tröger et al., 2001, p. 151, pl. 1, fig. 1; text-fig. 7). In the study area, it is known from intervals 3, 4 and 5 in the Aachen area, corresponding to the Belemnella cimbrica Zone and lower Belemnitella junior Zone (= Spyridoceramus tegulatus/Belemnitella junior Zone).

Cataceramus cf. oviformis Walaszczyk, Cobban \& Harries, 2001

Fig. 4/4.

\section{Material}

A single specimen: NHMM NK 37 (Schurzelterstraße, interval 3).

\section{Description and remarks}

This species is represented by a single internal mould of a left valve, of moderate size $\left(L_{\max }=55 \mathrm{~mm}\right)$. The valve is incomplete, lacking the postero-ventral portion. The specimen shows a characteristic valve outline, with the beak located more dorsocentrally, and with a strongly convex anterior margin. The valve is covered with regular concentric rugae, with their size and interspaces increasing gradually ventrally. The posterior auricle is not separated; the hinge line is long and straight.

The specimen closely corresponds to the typical features of Cataceramus oviformis, an early Maastrichtian species from the United States Gulf Coast and Montana (Walaszczyk et al., 2001, p. 166, pl. 41, fig. 3). On account of incomplete preservation, specific assignment is tentative.

\section{Occurrence}

Cataceramus oviformis occurs widely in the lower Maastrichtian of the Euramerican region; it is known from the United States Western Interior, Gulf Coast, from the Endocostea typica Zone at Tercis les Bains and from the Maastrichtian (possibly lower) of Daghestan (Caucasus).

Cataceramus cf. subcircularis (Meek, 1876)

Fig. 3/6.

1995 Inoceramus sp. 2; Keutgen, p. 309, pl. 8, fig. 3. 

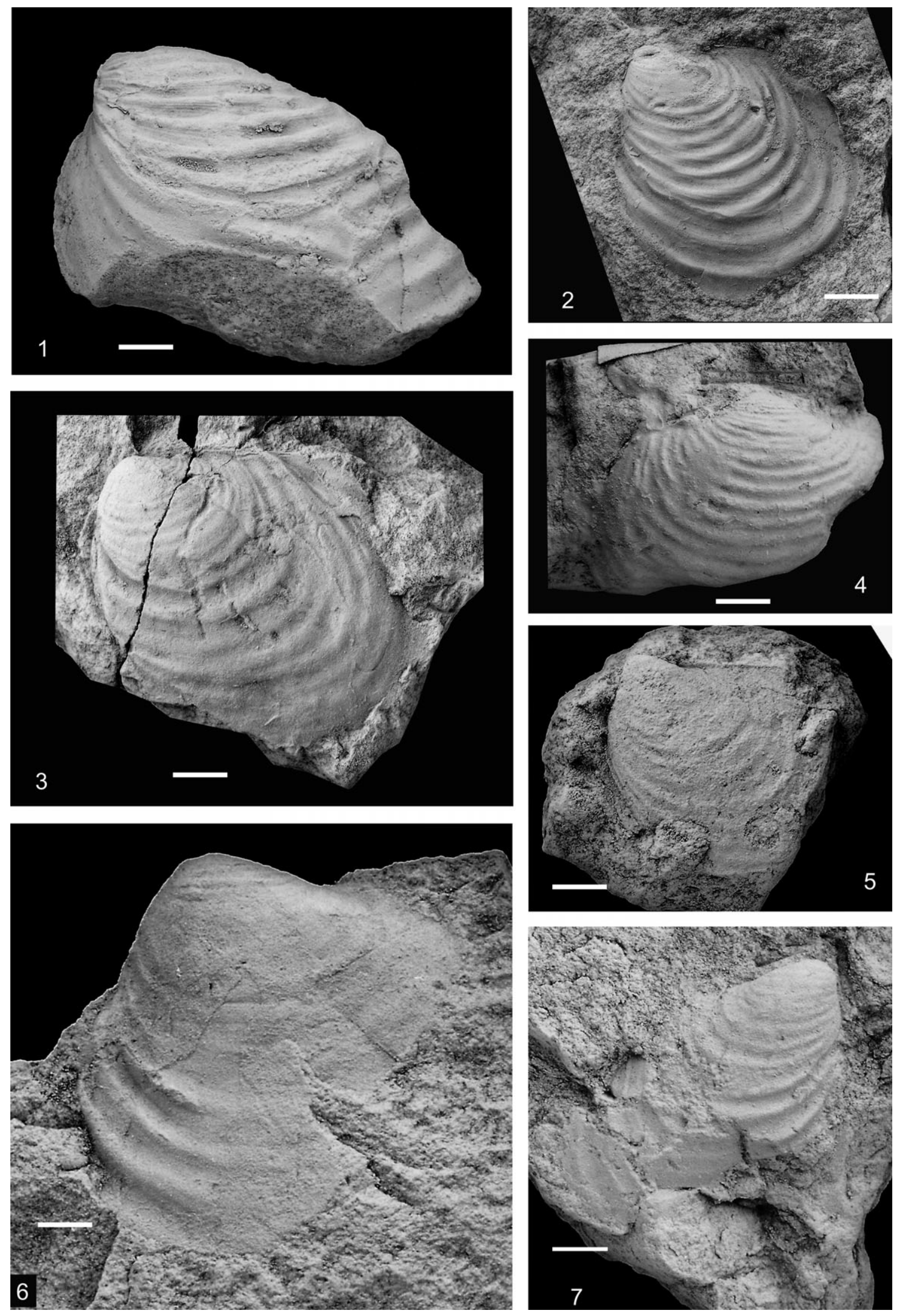

Fig. 4. Inoceramids of the Vijlen Member; 1. 'Inoceramus' sp. (NHMM NK 35; Lemiers-Schneeberg, ?interval 3); 2, 3, 7. Cataceramus glendivensis Walaszczyk, Cobban \& Harries, 2001 (NHMM NK 24; Hans-Böckler-Allee, interval 5; NHMM NK 38; Hans-Böckler-Allee, interval 4; NHMM NK 2; Hans-BöcklerAllee, interval 4); 4. Cataceramus cf. oviformis Walaszczyk, Cobban \& Harries, 2001 (NHMM NK 37; Schurzelterstraße, interval 3); 5. Cataceramus barabini (Morton, 1834) sensu Meek, 1876 (NHMM NK 5; Hans-Böckler-Allee, interval 4); 6. Platyceramus cf. salisburgensis (Fugger \& Kastner, 1885) (NHMM NK 4; Schurzelterstraße, interval 3). All scale bars represent $10 \mathrm{~mm}$. 


\section{Material}

A single specimen: NHMM NK 18 II (Hans-Böckler-Allee, interval 4).

\section{Description and remarks}

This specimen, of moderate size $\left(h_{\max }=64 \mathrm{~mm}\right)$, is deformed, but its regular commarginal rugae, regularly spaced, and apparently regular original outline allow it to be referred to this species, albeit questionably. The subcircularis morphotype is quite common at most localities exposing lower Maastrichtian strata. Based on observations within the Euramerican biogeographical region, early representatives of the taxon (in the uppermost Campanian and lowermost Maastrichtian) are small sized and then display a gradual size increase, at least up to the mid-lower Maastrichtian, within the Trochoceramus radiosus Zone (Walaszczyk et al., 2001). The larger representatives from the upper lower Maastrichtian have invariably been referred to a number of other species, e.g. Cataceramus buguntaensis (Dobrov \& Pavlova, 1959), Endocostea (Selenoceramus) semaili Morris, 1995 or 'Inoceramus' mandembataensis Sornay, 1973. All these names were synonymised with $C$. subcircularis by Walaszczyk et al. (2001); however, more detailed studies may reveal that a subdivision of the subcircularis lineage into two (?or three) chronosubspecies is possible, for which these names would then be available.

\section{Genus Endocostea Whitfield, 1877}

\section{Type species}

Endocostea typica Whitfield, 1877 (see Walaszczyk et al., 2001, for comments on the genus).

\section{Endocostea cf. jolkicevi Walaszczyk, Odin \& Dhondt, 2002}

Fig. 3/1.

\section{Material}

A single specimen: NHMM NK 17 (Schurzelterstraße, interval 3).

\section{Description and remarks}

This is an internal mould of a single right valve, with $\mathrm{L}$ and $\mathrm{H}$ approximately 50 and $43 \mathrm{~mm}$, respectively. The valve lacks the umbo and is rather poorly preserved in the dorsal and posterior portions. It shows two distinct growth stages; the juvenile, about $28 \mathrm{~mm}$ in $\mathrm{H}$ and the adult, growing at the same obliquity angle (with $\delta$ about $45^{\circ}$ ), but being distinctly geniculated, with an angle about $45^{\circ}$. The valve has a well-separated, narrow, elongated posterior auricle, at least in the adult stage. The juvenile part is weakly inflated, trapezoidal in outline; its anterior margin is straight, slightly concave below the umbo, then it passes at almost right angle into broadly rounded ventral margin, and then into short, almost straight posterior margin. The juvenile ornament is composed of distinct, closely spaced commarginal rugae, with narrow and deep interspaces. The outline of the rugae shows the presence in the juvenile part of a distinct radial sulcus, located approximately in the axial part of the valve. The adult stage is almost smooth; the radial sulcus does not continue, or at least is not visible at this stage.

In outline and character of the juvenile rugae, and the inferred presence of the radial sulcus in the juvenile stage, this specimen approaches E. jolkicevi, first described from the lower Maastrichtian (lowermost E. typica Zone) at Tercis les Bains (Walaszczyk et al., 2002b, p. 39, pl. 13, fig. 9). Although the French specimen lacks the two growth stages, it is readily apparent in an American specimen (Baculites baculus Zone), here referred to this species, as illustrated by Walaszczyk et al. (2001, pl. 39, fig. 9), under the name of Endocostea sp.

\section{Occurrence}

This species is also known from the lower lower Maastrichtian of Tercis les Bains, as well as from Aimaki, Daghestan (Caucasus; see Walaszczyk et al., 1996, pl. 4, fig. 1, as 'Inoceramus' ex gr. impressus) and from the United States Western Interior (Walaszczyk et al., 2001).

\section{Endocostea coxi (Reyment, 1955)}

Fig. 8/1(?), 2-3.

1955 Inoceramus coxi Reyment, p. 140, pl. 3, fig. 4.

2009 Endocostea coxi (Reyment, 1955); Walaszczyk et al., p. 72, figs 41A, G; 44C-E, G; 46A-F, ?G; 47A-F (with additional synonymy).

\section{Type}

Holotype, by original designation, is NHM L82963, from the Maastrichtian of Auchi, Nigeria.

\section{Material}

Three specimens: NHMM NK 25 (Hans-Böckler-Allee, interval 5) and NHMM NK 6 and NK 27 (Wilkensberg, uppermost portion of interval 5, plus interval 6).

\section{Description and remarks}

The species is represented by three specimens of variable preservation. The best preserved is NK 6 (with $h_{\max }=82 \mathrm{~mm}$ ), an internal mould of a single, complete right valve, composed of a juvenile stage comparable with that of the type of the species, followed by extended ventrally adult stage (Fig. 8/3). The specimen is moderately laterally compressed and, moreover, it lacks the postero-ventral part of the juvenile stage. The juvenile stage is a posteriorly elongated part $(\mathrm{H} / \mathrm{L}$ ratio at the juvenile/adult stage boundary is 0.6), with typical Endocosteatype morphology. It is strongly inflated in the umbonal part, with the beak located antero-posteriorly. The posterior auricle 


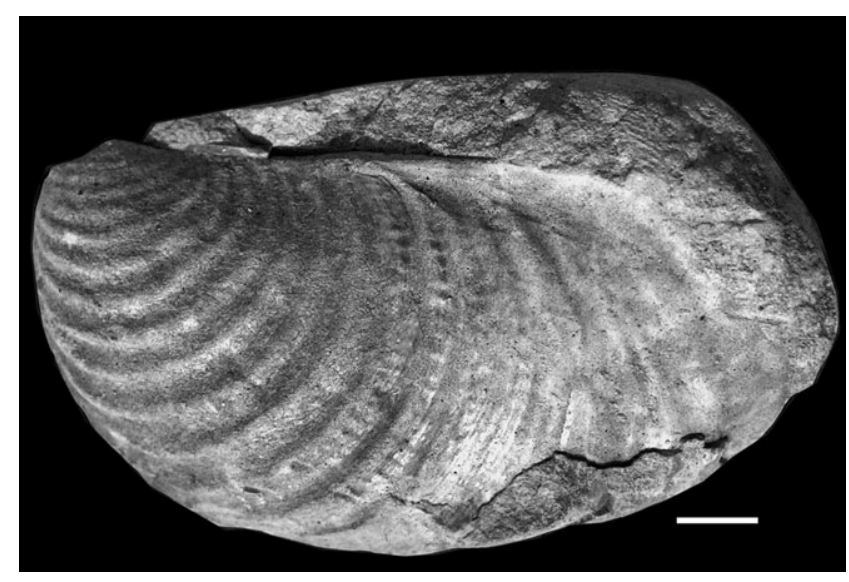

Fig. 5. Trochoceramus cf. radiosus (Quaas, 1902), from 'Kalkstein von Vijlen' near Vaals; UB, unregistered specimen. Scale bar represents $10 \mathrm{~mm}$.

is well separated from the disc. In the adult stage, the valve starts growing postero-ventrally; the adult $\delta$ value is estimated at about $60^{\circ}$; the adult valve outline becomes trapezoidal (with $\mathrm{H} / \mathrm{L}$ ratio about 1 ). The anterior margin is relatively long with relatively high anterior face. The juvenile ornament is composed of closely and quite regularly spaced, sharp-edged rugae; in the adult stage the ruage are more widely spaced, with interspaces increasing subregularly ventrally.

The two other specimens (NHMM MK 25 and 27) are juvenile fragments. MK 25 (Fig. 8/1) is represented by the external mould of the juvenile and small part of the adult stages of a left valve, whereas MK 27 (Fig. 8/2) is a deformed juvenile fragment of a left valve, which shows its original inflation. Although, for the time being, MK 25 is referred herein to $E$. coxi, it is possible that it represents 'I.' ianjonaensis with strong concentric ornament in the juvenile stage and with much more distinct ornament in the adult, similar to specimen NHMM JJ 2812 (Fig. 7/9).

\section{Occurrence}

In the study area, this species is confined to intervals 5 and 6 , corresponding to the lower Belemnitella junior Zone (= Spyridoceramus tegulatus/Belemnitella junior Zone). The species is known from equivalent horizons in Nigeria (Reyment, 1955; López et al., 2004) and Zululand (Walaszczyk et al., 2009).

Genus Platyceramus Heinz, 1932

\section{Type species}

Inoceramus mantelli (De Mercey) Barrois, 1879.

Platyceramus stephensoni (Walaszczyk, Cobban \& Harries, 2001)

Fig. 6. pars1994 Inoceramus (Platyceramus) aff. I. (Pl.) cycloides Wegner, 1905; MacLeod, p. 1061, figs 7.1, 8.2, 9.5, 9.6, 12.5 (non 11.3, 'Inoceramus' sp.).

1995 Inoceramus (Platyceramus) sp.; Keutgen, p. 300, pl. 7, fig. 2.

2001 'Inoceramus' stephensoni Walaszczyk et al., p. 223, pl. 41, fig. 6; pl. 42, fig. 5, pl. 44, fig. 3.

\section{Type}

Holotype, by original designation, is USNM 507487, the original of 'Inoceramus' stephensoni in Walaszczyk et al. (2001, pl. 44, fig. 3), from the Baculites grandis Zone of Weston County, Wyoming.

\section{Material}

One specimen, illustrated by Keutgen (1995, pl. 7, fig. 2), and reillustrated herein (Fig. 6), plus two additional specimens (not illustrated) from the same locality and level (Hans-BöcklerAllee, interval 5). These specimens (unregistered) are now contained in the collections of the Museen der Stadt Aachen (MSA).

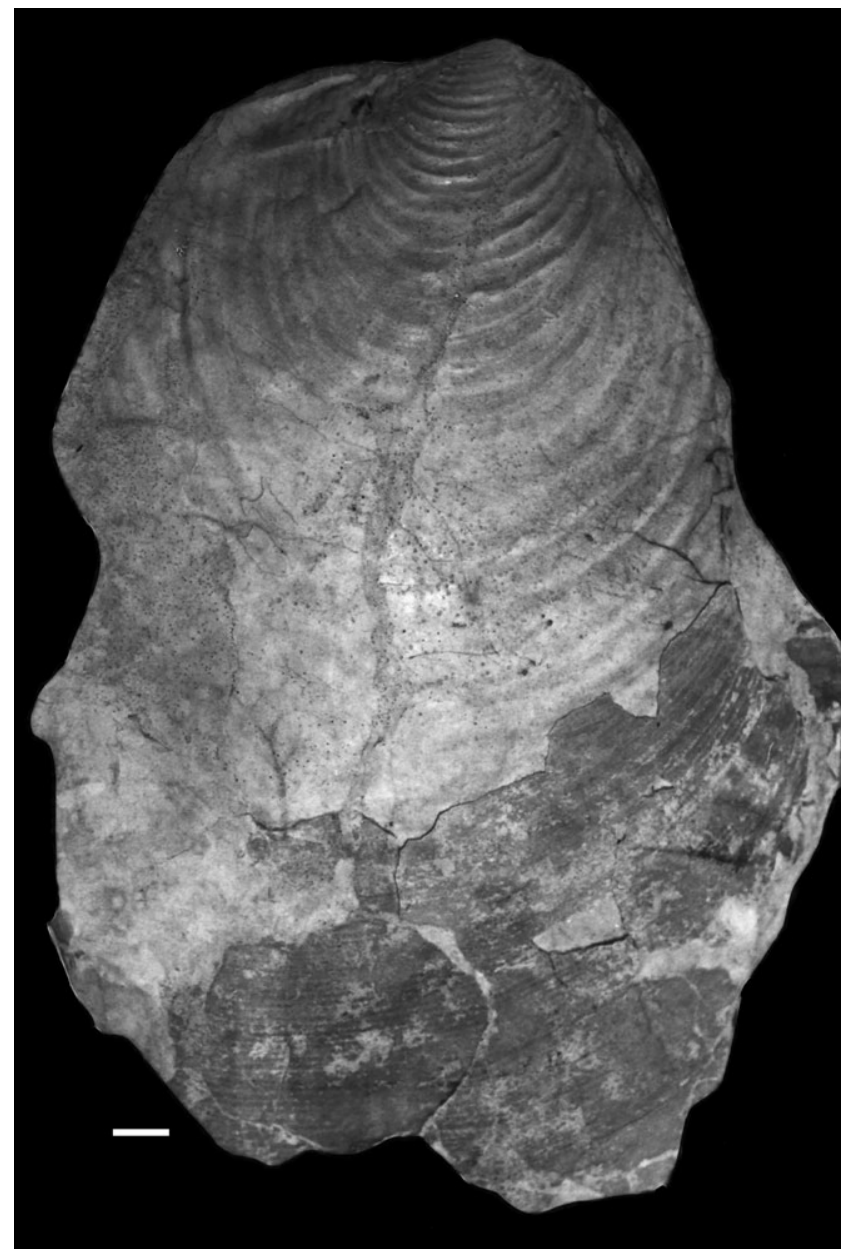

Fig. 6. Platyceramus stephensoni (Walaszczyk, Cobban \& Harries, 2001) (MSA unregistered; Hans-Böckler-Allee, interval 5). Scale bar represents $10 \mathrm{~mm}$. 


\section{Description}

The illustrated specimen is a single right valve. It is a huge specimen, with $h_{\max }=135 \mathrm{~mm}$. It is nearly flat; only the umbo is weakly inflated. The valve outline is subrectangular, almost twice as long along $\mathrm{h}$ than along $\mathrm{b}$. The beak is small, projecting slightly above the hinge line. The hinge line is moderately long and straight. The anterior margin is long, broadly convex, then it passes into rounded ventral margin. The posterior margin fragmentarily preserved. The disc is separated from the posterior auricle only in the peri-umbonal region.

Both the juvenile and adult valve stages are covered with quite regular concentric rugae, which increase in size and in interspaces ventrally. The gerontic stage is covered with irregular, low, widely spaced rugae and with growth lines, well seen on the shelly fragments.

\section{Remarks}

These specimens are indistinguishable from forms referred to Platyceramus cycloides group in the Santonian and lower lower Campanian (illustrated and described at length by Seitz, 1961); the temporal gap separating the two occurrences is the basis for referring such forms in the upper lower Maastrichtian to another species.

\section{Occurrence}

This species was described from the upper Baculites baculus and from the Baculites grandis Zones of the United States Western Interior (Walaszczyk et al., 2001) and has also been recorded from the lower Maastrichtian of Austria (Tröger et al., 2001), and is well represented in the upper lower Maastrichtian of Zululand (Walaszczyk et al., 2009).

Platyceramus cf. salisburgensis (Fugger \& Kastner, 1885)

Fig. 4/6.

Compare:

1970 Inoceramus (Platyceramus) salisburgensis Fugger \& Kastner; Seitz, p. 125, pl. 24, fig. 1; pls 25-27; text-fig. 11.

\section{Material}

A single specimen: NHMM NK 4 (Schurzelterstraße, interval 3).

\section{Description and remarks}

This is an internal mould of a single, incomplete left valve, with an estimated maximum $\mathrm{h}$ of $74 \mathrm{~mm}$ and with $\mathrm{L}=72 \mathrm{~mm}$. It shows the small, raised umbonal portion and a flat, extended adult stage; the hinge line itself is only partially preserved, and its characteristics cannot be described. The anterior margin is straight. The antero-ventral and ventral margins are rounded. The valve is weakly oblique, with $\delta=68^{\circ}$. The ornament is composed of commarginal rugae. The rugae are fine and closely spaced in the umbonal part. The adult rugae are relatively widely spaced and irregular, best developed in the anterior part of the disc.

The specimen corresponds well to the Zululand material from equivalent upper lower Maastrichtian strata (see Walaszczyk et al., 2009, figs 32, 33, 36, 37, 38A, F, 39A). It is left in open nomenclature due to its incomplete preservation.

\section{Occurrence}

This species is known from the lower Maastrichtian of Austria, Rügen (northeast Germany) and Zululand; the present material is from interval 3, Belemnella cimbrica Zone.

\section{Inoceramids referred to the genus Inoceramus (sensu lato)}

Species with unknown generic affiliation are referred to the genus Inoceramus (sensu lato); to distinguish them from forms representing genuine Inoceramus (sensu stricto), quotation marks are used in generic assignment.

\section{'Inoceramus' ianjonaensis Sornay, 1973}

\section{Type}

Holotype, by original designation of Sornay (1973, pl. 1, fig. 3), is specimen no. 13-10 from the lower Maastrichtian of Mandembata, Madagascar.

\section{Remarks}

'Inoceramus' ianjonaensis, best characterised as a 'balticus'-like form with additional radial ornament, was one of the forms commonly referred to the genus Trochoceramus. The number of radially ribbed forms from an interval spanning the topmost Campanian-basal upper Maastrichtian, which could potentially be referred to Trochoceramus, has grown markedly, and the group has been shown to occur at least in Europe, West Asia, Africa, and North and South America. The progress in the stratigraphic recognition of the topmost Campanian and lower Maastrichtian has enabled a refinement of our knowledge of the group's record. More precise stratigraphy and better knowledge of particular species within the group have aided in constraining its evolutionary interpretation, and consequently also its taxonomy.

The group first appeared in the uppermost Campanian (topmost Nostoceras pozaryskii $=N$. hyatti Zone) (Walaszczyk et al., 2002a, b; Walaszczyk, 2004) and persisted until the final disappearance of the so-called 'true' inoceramids in the lowermost upper Maastrichtian (somewhere in the Belemnitella junior Zone, as shown herein). Furthermore, the group does not occur continuously throughout the entire interval, but, instead, is found in three distinct, stratigraphically narrow intervals. These are:

1. a level in the uppermost Campanian (upper, but not the topmost Nostoceras hyatti Zone); 
2. the mid-lower Maastrichtian, lower Trochoceramus radiosus Zone; and

3. basal upper Maastrichtian (as demonstrated herein), 'Inoceramus' ianjonaensis Zone, in the Belemnitella junior Zone; no representatives of the group occur in the intervals between.

Moreover, the morphotypes from particular intervals are closer morphologically to time-equivalent, non-radially ribbed forms than to members of the group from other intervals. Consequently, it is proposed that what is called the Trochoceramus group does not actually represent a single clade, which consequently could be referred to a single genus, but is rather composed of three independent, iteratively appearing lineages, in three successive time intervals. In ascending stratigraphic order these are:

1. the 'Inoceramus' garridoi (Bataller, 1947) / 'I.' costaecus Khalafova, 1966 lineage, which evolved in the latest Campanian;

2. the Trochoceramus radiosus (Quaas, 1902) lineage, which evolved in the mid-early Maastrichtian; and

3. the 'I.' ianjonaensis Sornay, 1973 lineage, which first appeared slightly above the lower/upper Maastrichtian boundary, in terms of belemnite stratigraphy.

If this interpretation is correct, all members of the groups should no longer be referred to a single genus as the group is polyphyletic; only one of the lineages may be retained as Trochoceramus. Because the type species of the genus, i.e. 'Inoceramus' helveticus Heinz represents the mid-early Maastrichtian lineage, only those forms (assuming that they do in fact represent a lineage) should be assigned to Trochoceramus from now on. Members of the two other lineages must be referred to other genus-level taxa, or retained in parental genera. For the time being, we leave the reference of the lineage comprising Sornay's species ianjonaensis open and consequently place it in 'Inoceramus' (sensu lato).

\section{Subspecific interpretation}

In accordance with Walaszczyk et al. $(2002,2009)$ and López et al. (2004), we regard forms in Europe referred to 'I.' morgani as conspecific with 'I.' ianjonaensis Sornay. However, to indicate the differences in mean specimen size within populations of both taxa, as well some differences, e.g. in the dominance of particular morphotypes, we interpret 'I.' morgani as a geographic subspecies of 'I.' ianjonaensis.

'Inoceramus' ianjonaensis morgani Sornay, 1973

Fig. 7/1-13.

1973 Inoceramus (Trochoceramus) morgani Sornay, p. 91, pl. 3, figs 3, 4; pl. 4, figs 2, 3; text-fig. 5.
1987 Inoceramus sp. cf. I. balticus Böhm; Dhondt \& Jagt, p. 82, fig. 3.4.

1994 Inoceramus (Trochoceramus) morgani Sornay; MacLeod, p. 1059, figs 10.3, 10.6-10.8.

1995 Inoceramus (Selenoceramus) inaequabilis Seitz; Keutgen, p. 303, pl. 7, fig. 3 .

1995 Inoceramus (Trochoceramus) nahorianensis Kociubynskij; Keutgen, p. 305, pl. 7, fig. 4.

Type

Holotype, by original designation, is specimen no. M4, the original of Sornay (1973, pl. 4, fig. 6; text-fig. 5) from the Calcaire à Baculites of the Port-Filiolet near Picauville (Manche, France); Maastrichtian.

\section{Material}

Thirteen specimens: NHMM NK 7, NK 16, NK19 and NK 27a (all Wilkensberg, uppermost portion of interval 5, plus interval 6); NHMM JJ 2685b, JJ 2812, JJ 3090a/b, JJ 3893, JJ 3509, JJ 6447, JJ 6705, JJ 12204 and JJ 12266 (all Haccourt-Lixhe area, upper portion of interval 5, plus interval 6).

\section{Description}

This species is of small to moderate size, inequilateral, ?equivalved. The valves are distinctly geniculated. The juvenile stage, with $\mathrm{H}_{\max }$ not exceeding $28 \mathrm{~mm}$, is nearly flat, subrounded to subrectangular. The umbo is small, either projecting very slightly above the hinge line or not at all. The valves in this stage vary from almost upright to moderately oblique. The disc is not distinct. The juvenile ornament is composed of quite regularly spaced, concentric rugae that gradually increase in width towards the venter. Radial ornament is variably developed; best seen in a specimen with very weak obliquity (Fig. 7/4). The number of specimens is, however, too small to judge whether there is a positive relationship between the obliquity and radial ornament. The growth direction of the adult stage varies considerably and depends on the obliquity of the juvenile stage. It is ornamented either with regularly spaced rugae or is almost smooth. Numerous specimens bear a variously developed 'hohlkehle'.

\section{Remarks}

The description given fits particularly well the specimens from Wilkensberg (Fig. 7/1, 4, 8, 12). Some specimens from the Haccourt-Lixhe area, also referred herein to 'I.' ianjonaensis morgani, differ slightly; they possess smaller juvenile stages and relatively larger and better-ornamented adult stages (Fig. $7 / 9,13)$. On the one hand, as the source rocks of specimens from both localities are different (siliceous marls and chalk, respectively), this morphotypical variation may, to some extent, be due to facies and/or taphonomic controls. On the other hand, however, both morphotypes are also easily recognised in the material from Calcaire à Baculites (Walaszczyk, unpublished 

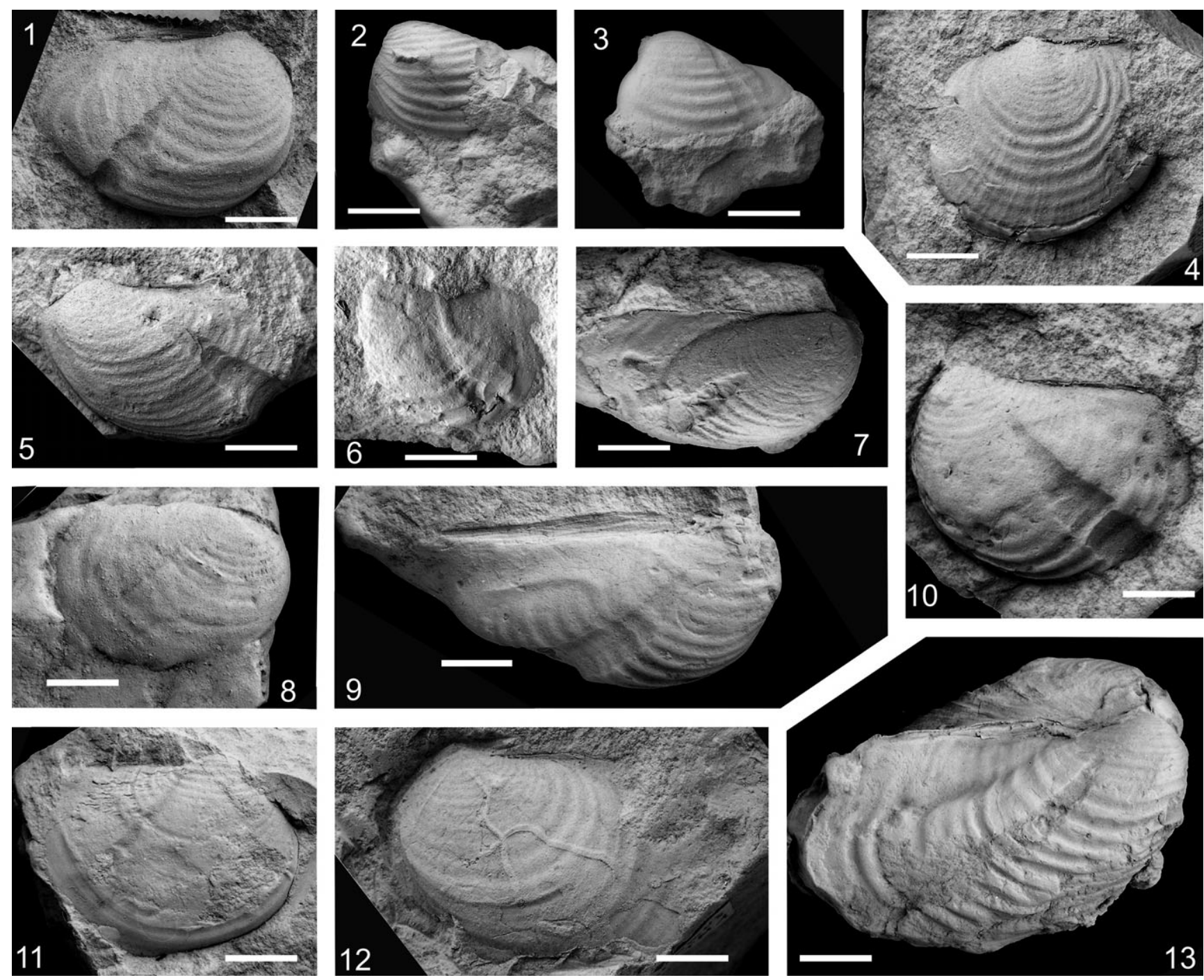

Fig. 7. Inoceramids of the Vijlen Member; 1-13. Inoceramus' ianjonaensis morgani (Sornay, 1973) (NHMM NK 7; Wilkensberg, interval 5; NHMM JJ 6705; CPL-Haccourt, interval 6; NHMM JJ 12266; CPL-Haccourt, interval 6; NHMM NK 16; Wilkensberg, interval 5; NHMM JJ 3090b; CPL-Haccourt, interval 6; NHMM JJ 12204; CPL-Haccourt, interval 6; NHMM JJ 3509; CPL-Haccourt, interval 6; NHMM NK 13; Wilkensberg, interval 5; NHMM JJ 2812; CPL-Haccourt, interval 6; NHMM JJ 2685b; CPL-Haccourt, interval 6; NHMM JJ 6447; CPL-Haccourt, interval 6; NHMM NK 19; Wilkensberg, interval 5; NHMM JJ 3893; CPL-Haccourt, interval 6 , respectively. All scale bars represent $10 \mathrm{~mm}$.

observations), where no facies dependence, based on lithology of rock fragements attached to the museum specimens, can be inferred. The studied material is not large enough to allow a final judgement, but it may appear reasonable to distinguish both morphotypes as separate taxa.

The material studied shows a wide range of morphological variation, mostly with respect to size of the juvenile stage, juvenile obliquity and the presence and strength of radial ornament. It matches well the variability of 'I.' ianjonaensis as observed within the rich material from Libya (Tröger \& Röhlich, 1991), Nigeria (López et al., 2004) and particularly from Zululand (Walaszczyk et al., 2009).

\section{Occurrence}

In the study area, 'I.' ianjonaensis morgani occurs in the uppermost portion of interval 5 and in interval 6, corresponding to the lower Belemnitella junior Zone. This level is roughly correlatable with the upper Spyridoceramus tegulatus/ Belemnitella junior Zone in northern Germany. The subspecies morgani is also known from Calcaire à Baculites, Manche (France), from a level in the upper Maastrichtian (see Kennedy, 1986) and from the Bay of Biscay sections (southwest France, northern Spain), where it ranges throughout the lowermost part of the Menuites fresvillensis Zone (MacLeod, 1994, fig. 4). The species 'I.' ianjonaensis is widely distributed in Africa (Libya, Nigeria, Zululand) and Madagascar.

'Inoceramus'sp.

Fig. 4/1. 


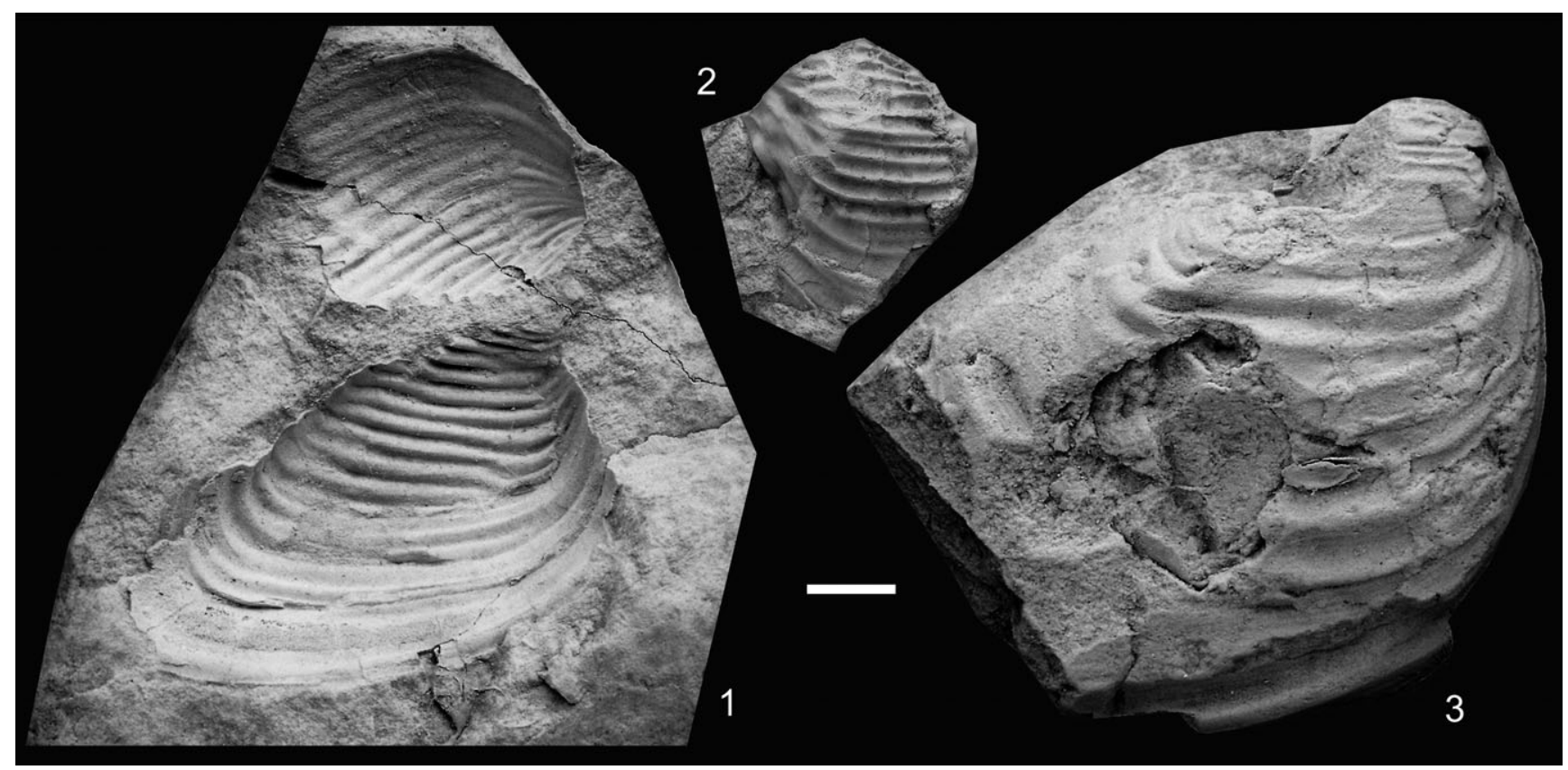

Fig. 8. Inoceramids of the Vijlen Member; 1-3. Endocostea coxi (Reyment, 1955) (NHMM NK 25; Hans-Böckler-Allee, interval 5; NHMM NK 27 and NHMM NK 6; both Wilkensberg, uppermost portion of interval 5, plus interval 6). All scale bars represent $10 \mathrm{~mm}$.

\section{Material}

A single specimen: NHMM NK 35 (Lemiers-Schneeberg; exact provenance from within the Vijlen Member is unknown, but may have originated from interval 3).

\section{Description and remarks}

This is a single internal mould of a left valve; incomplete, with its dorsal and posterior parts missing. Despite this, the specimen clearly displays the anterior position of the beak and two growth stages; with the juvenile stage weakly inflated, quite large $\left(h_{\max }=66 \mathrm{~mm}\right)$ and the adult stage growing at a high angle in the anterior part and only weakly geniculated in the ventral and postero-ventral parts of the valve. The juvenile stage is covered with regularly spaced, sharp concentric rugae, with deep interspaces; the rugae are distinctly oblique in that portion of the valve anterior to the growth axis.

The type of ornament makes the specimen close to 'endocostean' inoceramids (see above, under Endocostea cf. jolkicevi). Rugae obliquity has been noted for numerous Late Cretaceous inoceramids, and in the Maastrichtian it is a feature found in trochoceramids and some Cataceramus-like forms.

\section{Occurrence}

Known only from ?interval 3, equating with the Belemnella cimbrica Zone.

\section{Genus Spyridoceramus Heinz, 1932}

\section{Type species}

Inoceramus tegulatus Von Hagenow, 1842 (non Ødum, 1922).
Spyridoceramus tegulatus (von Hagenow, 1842)

Fig. 9/1-8.

1842 Inoceramus tegulatus Von Hagenow, p. 559.

1932 Inoceramus (Spyridoceramus) tegulatus v. Hagenow; Wolansky, p. 28, pl. 4, fig. 5; pl. 5, figs 5, 6.

non1959 Inoceramus tegulatus v. Hagenow; Dobrov \& Pavlova, p. 150, pl. 23, figs 1-4 (= Tenuipteria argentea).

1986 Spyridoceramus tegulatus v. Hagenow; Abdel-Gawad, p. 146, pl. 31, figs 1, 2 (plus additional synonymy).

1995 Spyridoceramus tegulatus (von Hagenow); Keutgen, p. 311, pl. 8, fig. 4.

2001 Spyridoceramus cf. tegulatus (Hagenow); Tröger et al., p. 156, pl. 1, fig. 6; pl. 3, fig. 2; text-fig. 12.

\section{Type}

Lectotype, by subsequent designation of Speden (1970, p. 6), is the original of Wolansky (1932, pl. 5, fig. 6) from the lower Maastrichtian of Rügen (northeast Germany), a specimen from Von Hagenow's original collection.

\section{Material}

Sixteen specimens: NHMM NK 12 and NK 15A, B (both Schurzelterstraße, interval 3); NHMM NK 18 I, 22, 29 (external and internal moulds of the same specimen; Vaalserstraße, interval 4); NHMM NK 11A, B (two specimens; Hans-BöcklerAllee, interval 5); NHMM NK 32 and 20 (external and internal moulds of the same specimen) and NHMM NK 9 and 31 (internal and external mould of same specimen) (both Wilkensberg, uppermost portion of interval 5, plus interval unit 6); NHMM 

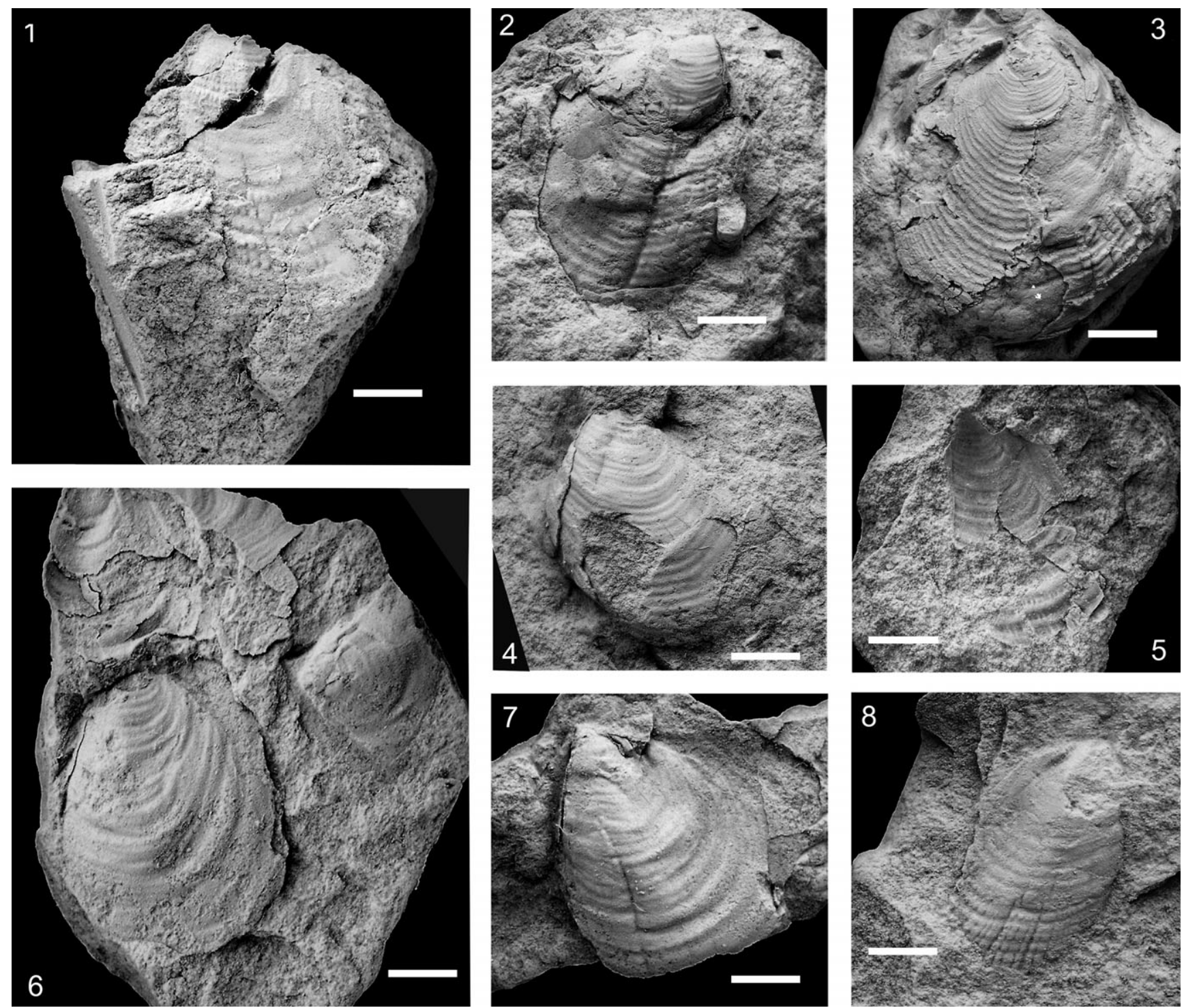

Fig. 9. Inoceramids of the Vijlen Member; 1, 5, 8. Spyridoceramus tegulatus (Von Hagenow, 1842) forma A (NHMM NK 18 I; Vaalserstraße, interval 4; NHMM NK $15 A$ and NHMM NK 12; Schurzelterstraße, interval 3). 2-4, 6-7. Spyridoceramus tegulatus (von Hagenow, 1842), forma B (NHMM JJ 6375b; CPL-Haccourt, interval 6; NHMM JJ 3898; CPL-Haccourt, interval 6; NHMM NK 9; Wilkensberg, interval 5; NHMM NK 11B and NK 11A; Hans-Böckler-Allee, interval 5, respectively). All scale bars represent $10 \mathrm{~mm}$.

NK 30A, B (strongly deformed; internal and external moulds of the same specimen), NHMM JJ 3898, JJ 4730, JJ 6375A-E, JJ 7011 and JJ 11853 (all CPL SA-Haccourt quarry, uppermost portion of interval 5, plus interval 6).

\section{Description and remarks}

Although the species is relatively common in the material studied, the actual number of specimens is rather low; altogether sixteen specimens, spanning intervals 3 to 6 . At least three morphotypes can be distinguished in the material, which are here referred to as formae A, B and C.

Specimens from interval 3 belong to forma $A$; these are axially elongated, slender, with concentric rugae dominating the ornament pattern (NHMM NK 12, 15A, B, 18, 22, 29) (Fig. 9/1, 5, 8); radial elements are in the form of discontinuous ribs, forming lines of nodes at the intersections with concentric rugae. This morphotype is the closest to illustrated specimens of Tenuipteria fibrosa (Meek \& Hayden, 1860) (e.g., Speden, 1970, pl. 1, figs 16; Wright, 1981, pl. 2, figs 6-11, plus pl. 2, figs 1-5 referred to Tenuipteria concentrica). The type of Spyridoceramus tegulatus (illustrated by Wolansky, 1932, pl. 5, fig. 6), which, however, is incompletely preserved, belongs probably to the same variety.

A broader morphotype, forma $B$, with the ornament composed almost exclusively of concentric rugae (NHMM NK 11A, B, 9, 31) appears in interval 5 (Fig. 9/2-4, 6-7). The same morphotype appears to predominate in material from interval 6 (NHMM JJ 3898, 6375B-C, 6375A-E, 6375D; NHMM NK 30A, B). This wide morphotype resembles var. ravni of Inoceramus caucasicus of Dobrov (1951, p. 169, pl. 2, figs 9, 10). In the latter unit there are also two specimens (NHMM JJ 7011, JJ 11853) with very 
strong radial ornament, forma C. This variety resembles closely var. fistulata of Inoceramus caucasicus described by Dobrov (1951, p. 169, pl. 2, fig. 8), as well as one of Von Hagenow's syntypes illustrated by Wolansky (1932, pl. 4, fig. 5).

The morphotypes recognised in our material potentially could have stratigraphic implications, but the low number of specimens precludes any definitive interpretation. The observed variability within Spyridoceramus tegulatus (see e.g. Dobrov, 1951) may appear to be a reflection of the evolutionary pattern within the tegulatus lineage, and consequently, could be used for taxonomic and stratigraphic purposes. The report by Kauffman et al. (1993) and the study by Wright (1981) suggest that there may be this potential; however, no precise stratophenetic analysis of the European material has been carried out yet.

\section{Occurrence}

In the United States Western Interior, the oldest representative of the Tenuipteria-Spyridoceramus group appears in the Baculites baculus Zone (Jeletzky, 1968), the base of which corresponds to the base of the Endocostea typica Zone. In the Wisła River sections, the oldest Sypridoceramus was reported from Dziurków quarry (Abdel-Gawad, 1986), within the Endocostea typica Zone, and corresponding, most probably, to the upper Belemnella pseudobtusa Zone. According to Dhondt (1982), S. tegulatus ranges up to the base of the Belemnitella junior Zone; reference is also made to Jagt (1999) for a brief discussion on the ranges of $S$. tegulatus and T. argentea in the type Maastrichtian.

\section{Acknowledgements}

IW wishes to thank the director of the Instytut Geologii Podstawowej for financial support; JWMJ and NK acknowledge the assistance of Dr A.C. Oellers while studying material now contained in the collections of the Museen der Stadt Aachen, and all authors thank Dr E.A. Jagt-Yazykova for her help in preparation of some figures and Dr P.J. Harries (University of South Florida, Tampa) for insightful comments on an earlier typescript.

\section{References}

Abdel-Gawad, G.I., 1986. Maastrichtian non-cephalopod mollusks (Scaphopoda, Gastropoda and Bivalvia) of the Middle Vistula Valley, Central Poland. Acta Geologica Polonica 36: 69-224.

Bataller, J.R., 1947. Sinopsis de las especies nuevas del Cretácico de España. Memorias de la Real Academia de Ciencias y Artes de Barcelona (3)28: 279-392.

Barrois, C., 1879. Sur quelques espèces nouvelles ou peu connues du terrain crétacé du nord de la France. Annales de la Société géologique du Nord 6: 449-457.

Böhm, J., 1907. Über Inoceramus Cripsi Mant. Zeitschrift der deutschen geologischen Gesellschaft 59: 113-114.
Christensen, W.K., 1997. The Late Cretaceous belemnite family Belemnitellidae: taxonomy and evolutionary history. Bulletin of the Geological Society of Denmark 44: 59-88.

Christensen, W.K., Schmid, F. \& Schulz, M.-G., 2004. Belemnitella from the Upper Maastrichtian of Hemmoor, Northwest Germany. Geologisches Jahrbuch A157: 23-67.

Dhondt, A.V., 1982. Bivalvia (Mollusca) from the Maastrichtian in Hemmoor (NW Germany), and their palaeobiogeographical affinities. Geologisches Jahrbuch A61: 73-107.

Dhondt, A.V. \& Jagt, J.W.M., 1987. Bivalvia uit de Kalksteen van Vijlen in Hallembaye (België). Grondboor en Hamer 41: 78-90.

Dobrov, S.A., 1951. Gruppa Inoceramus caucasicus n. sp. - Inoceramus tegulatus Hag. na severnom Kavkaze. Sbornik pamiati Akademika A.D. Arkhangelskovo, Voprosy Litologii i Stratigrafii SSSR (Moskva): 163-172.

Dobrov, S.A. \& Pavlova, M.M., 1959. Inoceramidae. In: Moskvin, M.M. (ed.): Atlas verkhnemelovoj fauny severnogo Kavkaza u Kryma, Gostoptechisdat (Moskva): 130-165.

Felder, P.J., 1997. The Vijlen Chalk Member (Maastrichtian, Late Cretaceous) in the Meuse-Rhine Euregion. Annales de la Société géologique de Belgique 119 (for 1996): 119-133.

Felder, P.J., 2001. Bioklasten-stratigrafie of ecozonatie voor het krijt (sic) (Santoniaan-Campaniaan-Maastrichtiaan) van Zuid-Limburg en oostelijk België. Memoirs of the Geological Survey of Belgium 47: 1-141.

Felder, P.J. \& Bless, M.J.M., 1994. The Vijlen Chalk (early Early to early Late Maastrichtian) in its type area around Vijlen and Mamelis (southern Limburg, the Netherlands). Annales de la Société géologique de Belgique 116 (1993): 61-85.

Felder, W.M., 1975. Lithostratigrafie van het Boven-Krijt en het Dano-Montien in Zuid-Limburg en het aangrenzende gebied. In: Zagwijn, W.H. \& Van Staalduinen, C.J. (eds): Toelichting bij geologische overzichtskaarten van Nederland, Rijks Geologische Dienst (Haarlem): 63-72.

Giebel, C.G., 1852. Allgemeine Paläontologie: Entwurf einer systematischen Darstellung der Fauna und Flora der Vorwelt. Ambrosius Abel (Leipzig), 413 pp.

Harries, P.J., Kauffman, E.G., Crampton, J.S., Bengtson, P., Čech, P., Crame, J.A., Dhondt, A.V., Ernst, G., Hilbrecht, H., Lopez, G., Mortimore, R., Tröger, K.-A., Walaszczyk, I. \& Wood, C.J., 1996. Lower Turonian Euramerican Inoceramidae: a morphologic, taxonomic, and biostratigraphic overview. A report from the First Workshop on Early Turonian Inoceramids (0ct. 5-8, 1992) in Hamburg, Germany; organized by Heinz Hilbrecht and Peter J. Harries. Mitteilungen aus dem Geologisch-Paläontologischen Institut der Universität Hamburg 77 (Jost Wiedmann Memorial Volume): 641-671.

Heinz, R., 1932. Aus der neuen Systematik der Inoceramen. Mitteilungen aus dem mineralogisch-geologischen Staatsinstitut Hamburg 13: 1-26.

Hiltermann, H. \& Koch, W., 1950. Taxonomie und Vertikalverbreitung von Bolivinoides-Arten im Senon Nordwestdeutschlands. Geologisches Jahrbuch 64: 595-632.

Hofker, J., 1966. Maestrichtian, Danian and Paleocene Foraminifera. The Foraminifera of the type Maestrichtian in South Limburg, Netherlands, together with the Foraminifera of the underlying Gulpen Chalk and the overlying calcareous sediments; the Foraminifera of the Dansk Chalk and the overlying Greensands and Clays as found in Denmark. Palaeontographica, Supplement A10: ii + 1-376. 
Jagt, J.W.M., 1999. Late Cretaceous-Early Palaeogene echinoderms and the K/T boundary in the southeast Netherlands and northeastern Belgium - Part 1: Introduction and stratigraphy. Scripta Geologica 116: 1-57.

Jagt, J.W.M., Deckers, M., Dhondt, A.V., Dortangs, R.W., Felder, P.J., Felder, W.M., Jäger, M., Keutgen, N., Kuypers, M., Michels, G,. Reynders, J., Simon, E., Van der Ham, R., Van Knippenberg, P. \& Van Neer, R., 1995. Preliminary report of field work at Altembroeck (NE Belgium, early Maastrichtian). Belgische Geologische Dienst, Professional Paper 1995/1: 1-20.

Jagt, J.W.M., Kennedy, W.J. \& Burnett, J., 1992. Acanthoscaphites tridens (Kner, 1848) (Ammonoidea) from the Vijlen Member (Lower Maastrichtian) of Gulpen, Limburg, the Netherlands. Geologie en Mijnbouw 71: 15-21.

Jagt, J.W.M., Kennedy, W.J. \& Machalski, M., 1999. Giant scaphitid ammonites from the Maastrichtian of Europe. Bulletin de l'Institut royal des Sciences naturelles de Belgique, Sciences de la Terre 69: 133-154.

Jeletzky, J.A., 1968. Macrofossil zones of the marine Cretaceous of the Western Interior of Canada and their correlation with the zones and stages of Europe and the Western Interior of the United States. Geological Survey of Canada, Paper 67-72: 1-66.

Kauffman, E.G., Sageman, B.B., Kirkland, J.I., Elder, W.P., Harries, P.J. \& Villamil, T., 1993. Molluscan biostratigraphy of the Cretaceous Western Interior Basin, North America. In: Caldwell, W.G.E. \& Kauffman, E.G. (eds): Evolution of the Western Interior Basin. Geological Association of Canada, Special Paper 39: 397-434.

Kennedy, W.J., 1986. The ammonite fauna fo the Calcaire à Baculites (Upper Maastrichtian) of the Cotentin Peninsula (Manche, France). Palaeontology 29: 25-83.

Keutgen, N., 1995. Biostratigraphie, Paläoökologie und Invertebratenfauna des Untermaastricht von Aachen (Westdeutschland) und angrenzenden Gebieten (Südostniederlande, Nordostbelgien). Aachen: Fakultät für Bergbau, Hüttenwesen und Geowissenschaften der Rheinischen-Westfälischen Technischen Hochschule Aachen, 546 pp. (unpubl. PhD thesis).

Keutgen, N., 1996. Biostratigraphie, Paläoökologie und Invertebratenfauna des Untermaastricht von Aachen (Westdeutschland) und angrenzenden Gebieten (Südostniederlande, Nordostbelgien). Shaker Verlag (Aachen), 213 pp.

Keutgen, N. \& Jagt, J.W.M., 2009. Correlation of Maastrichtian strata in the southeast Netherlands and adjacent regions, northern Germany, northern Spain and the USA. Byulleten' Moskovskogo Obshchestva Ispytatelej Prirody, Otdel Geologicheskii 84: 71-77.

Keutgen, N., Jagt, J.W.M., Felder, P.J. \& Jagt-Yazykova, E.A., 2010. Stratigraphy of the upper Vijlen Member (Gulpen Formation; Maastrichtian) in northeast Belgium, the southeast Netherlands and the Aachen city area (Germany), with special reference to belemnitellid cephalopods. Netherlands Journal of Geosciences (this volume).

Keutgen, N. \& Van der Tuuk, L.A., 1991. Belemnites from the Lower Maastrichtian of Limburg, Aachen and Liège. Mededelingen van de Rijks Geologische Dienst 44 (for 1990): 1-39.

Khalafova, R.A., 1966. (New species of inoceramids from Senonian outcrops in Daghestan). Izvestiya Akademiia Nauk Azerbaidjanskoi SSR 6: 23-30.

Kin, A., 2010. Early Maastrichtian ammonites and nautiloids from Hrebenne, southeast Poland, and phenotypic plasticity of Acanthoscaphites tridens (Kner, 1848). Cretaceous Research 31: 27-60.
Kner, $\boldsymbol{R}_{\text {., }}$ 1848. Versteinerungen des Kreidemergels von Lemberg und seiner Umgebung. W. Haidinger's naturwissenschaftliche Abhandlungen 3: 1-42, 5 pls.

Koch, W., 1977. Teil 2: Biostratigraphie in der Oberkreide und Taxonomie von Foraminiferen. Geologisches Jahrbuch A38: 11-123.

Kongiel, R., 1962. On belemnites from Maastrichtian, Campanian and Santonian sediments in the Middle Vistula Valley (Central Poland). Prace Muzeum Ziemi 5: 3-140.

Landman, N.H. \& Waage, K.M., 1993. Scaphitid ammonites of the Upper Cretaceous (Maastrichtian) Fox Hills Formation in South Dakota and Wyoming. Bulletin of the American Museum of Natural History 215: 1-257.

López, G., Dhondt, A.V., Lobitzer, H. \& Tröger, K.-A., 2004. Lower Maastrichtian inoceramids from Nigeria. Annalen des Naturhistorischen Museums in Wien 106A: 227-257.

Machalski, M., 2005. Late Maastrichtian and earliest Danian scaphitid ammonites from central Europe: taxonomy, evolution, and extinction. Acta Palaeontologica Polonica 50: 653-696.

Machalski, M., Jagt, J.W.M., Heinberg, C., Landman, N.H. \& Håkansson, E., 2009. Dańskie amonity - obecny stan wiedzy i perspektywy badań. Przegląd Geologiczny 57: 486-493.

Machalski, M., Jagt, J.W.M., Landman, N.H. \& Motchurova-Dekova, N., 2007. The highest records of North American scaphitid ammonites in the European Maastrichtian (Upper Cretaceous) and their stratigraphic implications. Acta Geologica Polonica 57: 169-185.

MacLeod, K.G., 1994. Extinction of inoceramid bivalves in Maastrichtian strata of the Bay of Biscay region of France and Spain. Journal of Paleontology 68: 1048-1066.

Marsson, T., 1878. Die Foraminiferen der weissen Schreibkreide der Insel Rügen. Mittheilungen des naturwissenschaftlichen Vereins für Neu-Vorpommern und Rügen in Greifswald 10: 115-196.

Meek, F.B., 1876. Invertebrate Cretaceous and Tertiary fossils of the Upper Missouri country. In: F.V. Hayden. Report of the United States Geological Survey of the Territories 9: lxiv $+629 \mathrm{pp}$.

Meek, F.B. \& Hayden, F.V., 1860. Description of new organic remains from the Tertiary, Cretaceous and Jurassic rocks of Nebraska. Proceedings of the Philadelphia Academy of Natural Sciences 12: 175-185.

Morris, N., 1995. Maastrichtian Inoceramidae from the United Arab EmiratesOman border region. Bulletin of the Natural History Museum London (Geology) 51: 257-265.

Morton, S.G., 1834. Synopsis of the organic remains of the Cretaceous Group of the United States. Key and Biddle (Philadelphia), 88 pp.

Naidin, D.P., 1952. Verkhnemelovye belemnity zapadnoj Ukrainy. Trudy Moskovskogo Geologo-Razvedochnogo Instituta imemi S. Ordzhinikidze 27: 1-126.

Niebuhr, B., 2003. Late Campanian and Early Maastrichtian ammonites from the white chalk of Kronsmoor (northern Germany) - taxonomy and stratigraphy. Acta Geologica Polonica 53: 257-281.

Niebuhr, B., 2006. Multistratigraphische Gliederung der norddeutschen Schreibkreide (Coniac bis Maastricht), Korrelation von Aufschlüssen und Bohrungen. Zeitschrift der deutschen Gesellschaft für Geowissenschaften 157: 245-262. 
Nowak, J., 1913. Untersuchungen über die Cephalopoden der oberen Kreide in Polen. III. Teil. Bulletin international de l'Académie des Sciences de Cracovie, Classe des Sciences mathématiques et naturelles B1913: 335-415.

Odin, G.S. (ed.), 2001. The Campanian-Maastrichtian stage boundary. Characterisation at Tercis les Bains (France) and correlation with Europe and other continents (Developments in palaeontology and stratigraphy 19). Elsevier (Amsterdam), xxviii + $881 \mathrm{pp}$.

Odin, G.S. \& Lamaurelle, M.A., 2001. The global Campanian-Maastrichtian stage boundary at Tercis les Bains, Landes, SW France. Episodes 4: 229-238.

Odin, G.S. \& Walaszczyk, I., 2003. Sur les inocérames de Tercis (Landes, France): le meilleur outil corrélatif entre Europe et Amérique du Nord autour de la limite Campanien-Maastrichtien. Compte Rendu Geoscience 335: 239-246.

Ødum, H., 1922. Inoceramus tegulatus v. Hag. i det danske Skrivekridt. Meddelelser fra det danske geologiske Forening 6: 1-13.

Quaas, A., 1902. Beitrag zur Kenntnis der Fauna der obersten Kreidebildungen in der libyschen Wüste. Die Fauna der Overwegischichten und der Blätterthone in der libyschen Wüste. Palaeontographica 30: 153-336.

Reiss, Z., 1954. Upper Cretaceous and Lower Tertiary Bolivinoides from Israel. Contributions of the Cushman Foundation for Foraminiferal Research 5: 154-167.

Remin, Z., 2007. Palaeontology and biostratigraphy of belemnites from the Upper Campanian and Lower Maastrichtian of the Middle Vistula section, central Poland. Warsaw: University of Warsaw, 163 pp. (unpubl. PhD thesis, in Polish).

Reyment, R.A., 1955. Upper Cretaceous Mollusca (Lamellibranchia and Gastropoda) from Nigeria. Colonial Geology and Mineral Resources 5: 127-155.

Robaszynski, F., Bless, M.J.M., Felder, P.J., Foucher, J.-C., Legoux, O., Manivit, H., Meessen, J.P.M.T. \& Van der Tuuk, L.A., 1985. The Campanian-Maastrichtian boundary in the chalky facies close to the type-Maastrichtian area. Bulletin des Centres de Recherches et d'Exploration-Production d'Elf-Aquitaine 9: 1-113.

Robaszynski, F., González Donoso, J.M., Linares, D., Amédro, F., Caron, M., Dupuis, C., Dhondt, A.V. \& Gartner, S., 2000. Le Crétacé supérieur de la région de Kalaat Senan, Tunisie centrale. Litho-biostratigraphie intégrée: zones d'ammonites, de foraminifères planctoniques et de nannofossiles du Turonien supérieur au Maastrichtien. Bulletin des Centres de Recherche et d'Exploration-Production d'Elf-Aquitaine 22: 359-490.

Schönfeld, J., Schulz, M.-G., McArthur, J.M., Burnett, J., Gale, A., Hambach, U., Hansen, H.J., Kennedy, W.J., Rasmussen, K.L., Thirlwall, M.F. \& Wray, D.S., 1986. New results on biostratigraphy, palaeomagnetism, geochemistry and correlation from the standard section for the Upper Cretaceous white chalk of northern Germany (Lägerdorf-Kronsmoor-Hemmoor). In: Spaeth, C. (ed.): New developments in Cretaceous research topics. Mitteilungen aus dem Geologisch-Paläontologischen Institut der Universität Hamburg 77 (Jost Wiedmann Memorial Volume): 545-575.

Schulz, M.-G., 1979. Morphometrisch-variationsstatistische Untersuchungen zur Phylogenie der Belemniten-Gattung Belemnella im Untermaastricht NW Europas. Geologisches Jahrbuch A47: 3-157.

Schulz, M.-G. \& Schmid, F., 1983. Das Ober-Maastricht von Hemmoor (N Deutschland): Faunenzonen-Gliederung und Korrelation mit dem Ober-Maastricht von Dänemark und Limburg. Newsletters on Stratigraphy 13: 21-39.

Schulz, M.-G., Ernst, G., Ernst, H. \& Schmid, F., 1984. Coniacian to Maastrichtian stage boundaries in the standard section for the Upper Cretaceous white chalk of NW Germany (Lägerdorf-Kronsmoor-Hemmoor): definitions and proposals. Bulletin of the Geological Society of Denmark 33: 203-215.
Seitz, O., 1961. Die Inoceramen des Santon von Nordwestdeutschland. I. Teil (Die Untergattungen Platyceramus, Cladoceramus und Cordiceramus). Beiheft zum Geologischen Jahrbuch 46: 1-186.

Seitz, 0., 1970. Über einige Inoceramen aus der Oberen Kreide. 2. Die Muntigler Inoceramenfauna und ihre Verbreitung im Ober-Campan und Maastricht. Beihefte zum Geologischen Jahrbuch 86: 105-171.

Seunes, J., 1890. Contributions à l'étude des céphalopodes du Crétacé supérieur de France. I. Ammonites du Calcaire à Baculites du Cotentin. Mémoires de la Société géologique de France, Paléontologie 2: 3-7, 9-13.

Sornay, J., 1973. Sur les inocérames du Maestrichtien de Madagascar et sur une espèce de la Craie à Baculites du NW de la France. Annales de Paléontologie (Invertébrés) 59: 83-93.

Sowerby, J., 1817. The Mineral Conchology of Great Britain; or coloured figures and descriptions of those remains of testaceous animals or shells, which have been preserved at various times and depths in the area, 2. The author (London): pls 151-186.

Speden, I.G., 1970. Generic status of the Inoceramus? tegulatus species group (Bivalvia) of the latest Cretaceous of North America and Europe. Postilla 145: 1-45.

Tröger, K.-A. \& Röhlich, P., 1981. Inoceramus (Selenoceramus) ghadamesensis n. sp. from the Upper Cretaceous of NW Libya. Vestník ústredniho Ústavu Geologiského 56: 169-175.

Tröger, K.-A. \& Röhlich, P., 1991. Campanian-Maastrichtian inoceramid (Bivalvia) assemblages from NW Libya. In: Salem, M.J., Hammuda, 0.S. \& Eliagoubi, B.A. (eds). The Geology of Libya, 5: 1357-1381. Elsevier (Amsterdam).

Tröger, K.-A., Summesberger, H. \& Wagreich, M., 2001. Early Maastrichtian (Late Cretaceous) inoceramids from the Piesting Formation (Gosau Group, Austria). Beiträge zur Paläontologie 26: 145-167.

Vandenberghe, N., Van Simaeys, S., Steurbaut, E., Jagt, J.W.M. \& Felder, P.J., 2004. Stratigraphic architecture of the Upper Cretaceous and Cenozoic along the southern border of the North Sea Basin in Belgium. Netherlands Journal of Geosciences / Geologie en Mijnbouw 83: 155-171.

Van der Ham, R. \& Van Birgelen, M., 1992. Zeeëgels uit het Maastrichtien van de Schneeberg en omgeving (Aken, Duitsland). Natuurhistorisch Maandblad 81: 139-153.

Visser, A.M., 1951. Monograph on the foraminifera of the type-locality of the Maestrichtian (South-Limburg, Netherlands). Leidse Geologische Mededelingen 16 (1950): 197-359.

Von Hagenow, F., 1842. Monographie der Rügen'schen Kreiderversteinerungen. III. Abtheilung: Mollusken. Neues Jahrbuch für Mineralogie, Geognosie, Geologie und Petrefaktenkunde 1842: 528-575.

Walaszczyk, I., 2004. Inoceramids and inoceramid biostratigraphy of the Upper Campanian to basal Maastrichian of the Middle Vistula River section, central Poland. Acta Geologica Polonica 54: 95-168.

Walaszczyk, I., Cobban, W.A. \& Harries, P.J., 2001. Incoeramids and inoceramid biostratigraphy of the Campanian and Maastrichtian of the United States Western Interior Basin. Revue de Paléobiologie 20: 117-234.

Walaszczyk, I., Cobban, W.A. \& Odin, G.S., 2002a. The inoceramid succession across the Campanian-Maastrichtian boundary. Bulletin of the Geological Society of Denmark 49: 53-60. 
Walaszczyk, I., Jagt, J.W.M. \& Keutgen, N., 2008. Inoceramus ianjonaensis Sornay, 1973 - an inoceramid marker for the base of the Upper Maastrichtian. International Geological Congress, 0slo 2008, August 6-14 ${ }^{\text {th }}$, HPS-10 Stratigraphical subdivisions of the Cretaceous System, State of the art, Abstracts, 1 pp.

Walaszczyk, I., Kennedy, W.J. \& Klinger, H.C., 2009. Cretaceous faunas from Zululand and Natal, South Africa. Systematic palaeontology and stratigraphical potential of the Upper Campanian-Maastrichtian Inoceramidae (Bivalvia). African Natural History 5: 49-132.

Walaszczyk, I., Odin, G.S. \& Dhondt, A.V., 2002b. Inoceramids from the Upper Campanina and Lower Maastrichtian of the Tercis section (SW France), the Global Stratotype Section and Point for the Campanian-Maastrichtian boundary; taxonomy, biostratigraphy and correlation potential. Acta Geologica Polonica 52: 269-305.

Walaszczyk, I., Smirnov, J.P. \& Tröger, K.-A., 1996. Trochoceramid bivalves (Inoceramidae) from the Lower Maastrichtian of Daghestan (Aimaki section, NE Caucasus) and south-central Poland. Acta Geologica Polonica 46: 141-164.

Ward, P.D. \& Kennedy, W.J., 1993. Maastrichtian ammonites from the Biscay region (France, Spain). The Paleontological Society Memoir 34: 1-58.

Ward, P.D., Kennedy, W.J., MacLeod, K.G. \& Mount, J.F., 1991. Ammonite and inoceramid bivalve extinction patterns in Cretaceous/Tertiary boundary sections of the Biscay region (southwestern France, northern Spain). Geology 19: 1181-1184.

Whitfield, R.P., 1877. Preliminary report on the palaeontology of the Black Hills. United States Geographical and Geological Survey of the Rocky Mountains Region, 49 pp. Powell.

Wolansky, D., 1932. Die Cephalopoden und Lamellibranchiaten der Ober-Kreide Pommerns. Abhandlungen aus dem geologisch-palaeontologischen Institut der Universität Greifswald 9: 1-72.

Wornardt, W.W., 2002. Revision of Sequences Boundaries and Maximum Flooding Surfaces: Jurassic to Recent. 2002 0ffshore Technology Conference, Houston, Texas U.S.A., 6-9 May 2002, 0TC 14072: 1-18.

Wright, E.M.M.K., 1981. Evolutionary patterns in the Cretaceous bivalve genus Tenuipteria. George Washington University, 97 pp. (unpubl. PhD thesis). 